\title{
Statistical Control of Software Process: A Systematic Review
}

\author{
Bibiana Y. Garcés MsC. Grupo TIC - Facultad de Ingenierías. Corporación Universitaria Comfacauca / bgarces@ \\ unicomfacauca.edu.co \\ Francisco J. Pino Ph.D Grupo IDIS - Facultad de Ingeniería Electrónica y Telecomunicaciones, Universidad del \\ Cauca / fjpino@unicauca.edu.co
}

\begin{abstract}
The Software Processes Improvement requires advanced techniques for the quantitative management process, so that from the analysis of the relevant indicators in the organization, actions can be taken to facilitate the decision-making process in favor of this improvement. Among the set of techniques, special attention is devoted to the Statistical Process Control (SPC), which has gained acceptance in enterprises preparing to attain high degrees of maturity in their processes, and require the establishment of measuring programs. SPC is useful in software development for several reasons. Control Charts help identify process shifts and abnormal variations. It is therefore pertinent to assess how successful SPG is in the context of software production. In this sense, we have not found any integrated proposal of quantitative management applied to distributed software development, processes that allow the attainment of important benefits, and, at the same time, that more organizations are improving their processes. These considerations motivate the need to define and carry out a Systematic Review to assess whether SPC is being used effectively and correctly, and to determine the main obstacles to a successful application of SPC in SPI efforts. Thus, the systematic review allows developing a rigorous analysis of the current state of the SPC, which is a starting point to address how it can be successfully used as a decision-making support tool in software-process improvement in agreement with the available empirical evidence reported in the literature.
\end{abstract}

KEYWORDS Statistical Process Control, Six Sigma, Software Process, Systematic Review

\section{Control estadístico de procesos en software: una revisión sistemática}

\begin{abstract}
RESUMEN La mejora de procesos software [Software Process Improvement, SPI requiere de técnicas avanzadas para la gestión cuantitativa, de modo que, a partir del análisis de los indicadores relevantes en la organización, se pueda facilitar la toma de decisiones para dicha mejora. Dentro del conjunto de técnicas merece especial atención el control estadístico de procesos (Statistical Process Control, SPC) que ha ido ganando aceptación en las empresas que se preparan para alcanzar altos grados de madurez en sus procesos y que lo requieren para la implementación de sus programas de medición. El artículo desarrolla una revisión sistemática para un análisis crítico del estado del arte sobre las técnicas del SPC más adecuadas que se pueden adoptar en la gestión cuantitativa de software. En este sentido, al no encontrar una propuesta integrada de gestión cuantitativa software para procesos distribuidos que permita beneficios importantes a medida que más organizaciones mejoraran sus procesos o a los gestores de proyectos de software, la revisión sistemática es el modo riguroso para evaluar y determinar herramientas, tecnologías, técnicas y métodos de aplicación de acuerdo con la evidencia empírica disponible reportada en la literatura.
\end{abstract}

PALABRAS CLAVE Control estadístico de procesos; Six Sig$m a$; procesos de software; mejora de procesos de software.

\section{Software em controle estatístico de pro- cessos: uma revisão sistemática}

RESUMO A melhoria de processos de software [Software Process Improvement, SPI] exige técnicas avançadas para a gestão quantitativa, de modo que, a partir da análise de indicadores relevantes na organização, seja possível facilitar a tomada de decisão para essa melhoria. Dentro do conjunto de técnicas, merece especial atenção o controle estatístico de processos (Statistical Process Control, SPC), que tem vindo a ganhar aceitação em empresas que estão preparadas para atingir um alto grau de maturidade em seus processos e que precisam dele para a implementação de seus programas de medição. $\mathrm{O}$ artigo desenvolve uma revisão sistemática para uma análise crítica do estado da arte das técnicas do SPC mais adequadas que podem ser adotadas na gestão quantitativa de software. Neste sentido, não encontrando uma proposta integrada de software de gestão quantitativa que possa permitir benefícios significativos uma vez que mais organizações irão melhorar seus processos ou aos gerentes de projetos de software, a revisão sistemática é uma maneira rigorosa para avaliar e definir ferramentas, tecnologias, técnicas e métodos de aplicação de acordo com a evidência empírica disponível relatada na literatura.

PALAVRAS-CHAVE Controle estatístico de processos; Six Sigma; processos de software; melhora de processos de software. 


\section{Introduction}

The systematic review is a means of assessing and interpreting all available information corresponding to a given research topic, which allows proper breadth, depth, rigor, and consistency in the analysis and a more efficient synthesis of the literature (Kitchenham, 2004).

The aim of this paper is to analyze critically the current state of the Statistical Process Control applied to software processes. According to the ISO/TR 10017 report, the usefulness of statistical techniques is easier control of the variability that can be observed in the behavior and outcome of practically all processes, even under seemingly stable conditions. The report also presents SPC within the set of statistical techniques used (ISO, 2003). The use of SPG in the software industry began in the 1980s when some researchers adopted it as a tool for process improvement (Burr \& Owen, 1996; Carleton $\&$ Florac, 1999). The vast majority of studies have referred to using SPC as a tool for improvement, although there are debates about its application in software engineering processes (Card, 1994; Lantzy, 1992) and the level of maturity that the organization must have. SPC is based on the use of control charts, from which performance is monitored and evaluated, after establishing the acceptable limits of operation of process variation and supervising its progress over time. From control charts can be extracted different indicators, some of them not used often in software processes as they differ profoundly from industrial processes sectors. Hence, in order to apply properly SPC in software processes it is essential to know the nature of such processes compared with manufacturing processes that have been applied SPC (Caivano, 2000).

In this vein, it is understood that the literature can help to determine the interest in the SPC and the use of this powerful tool in quantitative management of software engineering.

To carry out the systematic review process and definition of the protocol, the guidelines represented in FiguRE 1 have been followed. In general, a systematic review can be seen as a process consisting of three main stages: planning, execution, and reporting. Kitchenham (2007) provides more detail on how to set up and execute the systematic review.

This article describes in detail the search, the review process, and selection of studies to determine the point

\section{Introducción}

La revisión sistemática es un medio de evaluar e interpretar toda la información disponible, correspondiente a un determinado tema de investigación, que permite la debida amplitud, profundidad, rigor y coherencia en el análisis, para una más eficaz síntesis de la literatura (Kitchenham, 2004).

El objetivo de este trabajo es realizar un análisis crítico del estado actual del Control Estadístico de Procesos [SPC] aplicado a procesos software. Según el informe ISO/TR 10017, la utilidad de las técnicas estadísticas radica en que facilitan el control de la variabilidad que puede ser observada en el comportamiento y el resultado de prácticamente todos los procesos, aún bajo condiciones aparentemente estables. El informe además presenta a SPG dentro del conjunto de técnicas estadísticas más utilizadas (ISO, 2003). El uso de SPG en la industria del software comenzó en los años 80, cuando ciertos investigadores empezaron a utilizarlo como herramienta de mejora de procesos (Burr \& Owen, 1996; Carleton \& Florac, 1999). La gran mayoría de los estudios se han referido a la constatación de utilizar SPC como herramienta de mejora, aunque hay debates sobre su aplicación en los procesos de ingeniería de software (Card, 1994; Lantzy, 1992) y el nivel de madurez que debe tener la organización. SPC se basa en el uso de gráficos de control, a partir de los cuales se monitorea y evalúa el rendimiento, al establecer los límites aceptables de funcionamiento de la variación del proceso y supervisar su evolución en el tiempo. De las gráficas de control pueden ser extraídos diferentes indicadores, algunos de los cuales a menudo no se utilizan en los procesos Software, ya que difieren profundamente de los procesos de sectores industriales, de ahí que, a la hora de aplicar correctamente SPC en los procesos software es fundamental conocer la naturaleza de dichos procesos en comparación con los procesos de fabricación en los que se ha aplicado SPG (Caivano, 2000).

En este orden de ideas, se busca que la literatura pueda contribuir a determinar el interés en el SPC y el uso de esta potente herramienta en la gestión cuantitativa de la ingeniería del software.

Para llevar a cabo el proceso de revisión sistemática y definición del protocolo, se han seguido las directrices representadas en la Figura 1. En general, una revisión sistemática puede ser vista como un proceso constituido por tres etapas principales: planificación, realización y reporte. En Kitchenham (2007) pueden ser encontrados más detalle de cómo organizar y ejecutar la revisión sistemática.

El presente artículo describe los detalles de la búsqueda, el proceso de revisión y la selección de estudios para determinar el punto en qué se encuentra el enfoque de la investigación. La siguiente sección desarrolla el proceso de revisión sistemática en las siguientes actividades: i) formalizar las preguntas de investigación según el problema o los problemas que se enfrentan; ii) buscar la literatura disponible para pruebas de acuerdo con un protocolo sistemático y recuperar los datos de las fuentes identificadas para realizar un estado del arte del SPC y; iii) analizar las evidencias recolectadas y usarlo para apoyar la toma de decisiones y conclusiones que permitan establecer el punto de partida para definir la documentación para estructu- 


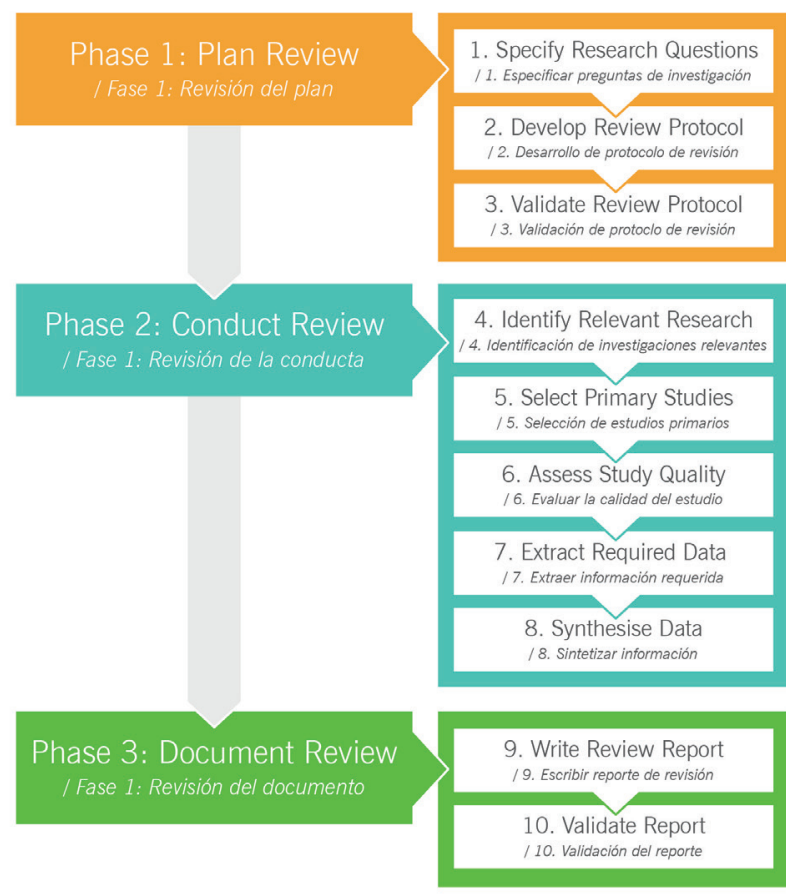

Figure 1. Stages of the Systematic Review Process of Literature / Etapas del Proceso de la Revisión Sistematica de la Literatura (Brereton, Kitchenham , Budgen, Turner, \& Khalil, 2005)

rar una metodología de implantación del SPC, donde se identifiquen los métodos más adecuados para aplicar SPC como una estrategia efectiva para la mejora de la gestión cuantitativa de los procesos software. Finalmente se presentan las principales conclusiones obtenidas y las líneas de trabajo futuro.

\section{Revisión sistemática del SPC}

Se propone llevar a cabo una revisión sistemática sobre la aplicación de las técnicas del SPG en procesos de producción de software. Para identificar lo que ha sido hecho y lo que se requiere, se lleva a cabo el proceso de revisión sistemática, siguiendo las directrices que indican que, en general, una revisión sistemática puede ser vista como un proceso constituido por tres etapas principales: planificación, realización y reporte de la revisión, las cuales se describen con mayor detalle en los siguientes sub-apartados.

\subsection{Planificación de la revisión}

La primera fase de la planificación requiere el enfoque de la investigación y el desarrollo y la validación del protocolo. Para llevar a cabo la revisión sistemática del control estadístico de procesos en ingeniería del software se siguió el protocolo que se presenta en Brereton, Kitchenham, Budgen, Turner, Y Khalil (2005), y las directrices para las revisiones sistemáticas que presenta Kitchenham (2007), junto con otras revisiones sistemáticas publicadas, como las de Baldassarre, Boffoli, Caivano, y Visaggio (2008); Pino, García, y Piattini (2007); y Genero, Fernández, Nelson, y Piattini (2011).

\subsubsection{Formulación de preguntas}

Enfoque. La investigación se aborda estableciendo un contexto general que define claramente los objetivos de la investigación, para of focus of the investigation. The next section develops the systematic review process in the following activities: i) formalize the research questions according to the problem or problems faced; ii) search the available literature for testing according to a systematic protocol and retrieve data from the identified sources to perform a state of the art of SPC; iii) analyze the evidence gathered and use it to support decision-making and conclusions that establish the starting point for defining the documentation to structure a methodology for implementation of SPC. Hence, the most appropriate methods can be identified for applying SPC as an effective strategy for improving the quantitative management of software processes. Finally, the main conclusions and lines of future work are presented.

\section{Systematic Review of the SPC}

It is proposed conducting a systematic review of the application of SPC techniques in software production processes. In order to identify what has been done and what is required, the systematic review process is carried out, following the guidelines indicating its general identification as a process consisting of three main stages planning, conducting, and report of the review - which are described in more detail in the following subsections.

\subsection{Planning of the review}

The first phase of the planning requires the focus of the research, development, and protocol validation. To conduct a systematic review of statistical control of process in software engineering the protocol presented in Brereton, Kitchenham, Budgen, Turner, and Khalil (2005) was followed, and the guidelines for systematic reviews of Kitchenham (2007), along with other published systematic reviews, such as that of Baldassarre, Boffoli, Caivano, and Visaggio (2008), Pino, García, and Piattini (2007), and Genero, Fernández, Nelson, and Piattini (2011).

\subsubsection{Questioning}

Approach. The research establishes a general framework that clearly defines the objectives of the investigation, to show various problems and formulate questions. The purpose of the questions is to identify, within the literature, the most important works that have focused on statistical process control for quantitative management in Software Engineering.

Issue. The companies' quality personnel who use SPC valuated in CMM Level 5 are often concerned that SPC 
does not seem to give significant benefits to the company or the managers of software projects. In particular, managers complain that information is not precise enough to help them with their productive activities. This seems to demonstrate that SPC techniques are not being adequately or properly used in the production of software, perhaps for the specific characteristics of software processes.

On the other hand, it is suggested that to assess whether SPG is being used effectively by professionals is of importance, because misuse of control charts usually arises from lack of statistical foundations that support them. According to Ruiz-Falcó (2006), control charts are often used incorrectly or the limitations are unknown. Additionally, when supporting management decisions, control charts, along with their indicators, the performance of the process is assessed in order to establish the acceptable limits of operation and variations thereof, as well as monitor and evaluate the evolution in time. However, many indicators that can be extracted from a control chart are not used often in the software processes that differ profoundly from manufacturing sectors (Lantzy, 1992).

SPC constitutes a diagnostic methodology of the stability of a quality indicator of a process and its ability to meet its specifications or tolerances (Ferreiro, 2010). In this context, the indicators that conform to the appropriate metrics and allow the characteristics to be established, limits and process capability by defining control charts are unknown, as are substantially unclear the processes within Engineering Software that require and can apply SPC.

In the context of control and monitoring there are no known methods to establish criteria for systematic monitoring, so the following problems (Baldassarre, Boffoli, Caivano, \& Visaggio, 2004) are evident: monitoring involves the need to define the appropriate thresholds and use them to evaluate the performance of what is expected, considering that you cannot set limits of universal validity due to the heterogeneity of the operating environments and the large number of monitored processes; identifying abnormal behavior and promptly react to this, so it is necessary to understand what is abnormal behavior and how it can be identified; and determining how to adjust the sensitivity of monitoring in the light of continuous change of the behavior of a process that quickly reflects the variation according to the observed phenomenon or process anomalies, monitoring criterion, and implemen- evidenciar varios problemas y formular las preguntas. El propósito de las preguntas es identificar, dentro de la literatura, las obras más relevantes que se han centrado en el control estadístico de procesos [SPC] para la gestión cuantitativa en Ingeniería de Software.

Problema. El personal de calidad de las empresas que utilizan SPC con valoración en CMM Nivel 5, a menudo se preocupa por que SPC no parece estar dando beneficios importantes a la empresa o a los gestores de proyectos de software. En particular, los gerentes se quejan de que la información no es suficientemente precisa para ayudarles con sus actividades productivas. Esto parece evidenciar que las técnicas de SPC no están siendo adecuada o correctamente utilizadas en la producción de software, tal vez por las características específicas de los procesos de software. Por otra parte, sugiere que es importante evaluar si SPC está siendo utilizada con eficacia por los profesionales, por lo que normalmente, la utilización incorrecta de los gráficos de control procede del desconocimiento de los fundamentos estadísticos que los sustentan. De acuerdo con Ruiz-Falcó (2006) a menudo se emplean los gráficos de control de modo incorrecto o se desconocen sus limitaciones. Adicionalmente, al apoyar las decisiones de gestión, los gráficos de control, junto con sus indicadores, evalúan el rendimiento del proceso para establecer los límites aceptables de funcionamiento y la variación del mismo, así como, supervisar y evaluar la evolución en el tiempo, pero muchos indicadores que pueden ser extraídos de un gráfico de control a menudo no se utilizan en los procesos software que profundamente difieren de los sectores industriales (Lantzy, 1992).

SPC constituye una metodología de diagnóstico de la estabilidad de un indicador de calidad de un proceso y de su capacidad para cumplir con sus especificaciones o límites de tolerancia (Ferreiro, 2010). En este orden de ideas, se desconocen los indicadores que conforman las métricas idóneas y que permiten establecer las características, los límites y la capacidad de los procesos, al definir los gráficos de control, así como substancialmente no son claros los procesos dentro de la Ingeniería del Software que requirieren y pueden aplicar SPC.

En el contexto del control y monitoreo son desconocidos métodos que establezcan criterios de seguimiento sistemático, por lo que se evidencian los siguientes problemas (Baldassarre, Boffoli, Caivano, \& Visaggio, 2004): el monitoreo implica la necesidad de definir los umbrales apropiados y usarlos para evaluar el desempeño de lo que se espera, considerando que no se pueden establecer límites de validez universal debido a la heterogeneidad de los entornos operativos y al considerable número de procesos monitoreados; la necesidad de identificar un comportamiento anormal y reaccionar oportunamente ante este, por lo cual se requiere entender lo que es un comportamiento anormal y la forma en que se pueden identificar; y la manera de ajustar la sensibilidad del monitoreo a la luz del continuo cambio del comportamiento de un proceso que refleje velozmente la variación en función del fenómeno observado o las anomalías en el proceso, los criterios de monitoreo y el método de implementación, para articular SPG a la gestión y, si es posible, aplicar SPC a empresas emergentes. En este 
Table 1. Research questions / Preguntas de la investigación

RQ1 What are the initiatives and experiences of SPG in Software Engineering, the SPC control charts being used, statistical techniques, and tools that complement its application? / ¿Cuáles son las iniciativas y experiencias del SPC en la Ingeniería del Softreare, los gráficos de control del SPC que están siendo utilizados, las técnicas estadísticas y las herramientas abordadas que complementan su aplicación?

RQ2 What are the benefits and limitations of SPC identified in the context of software, and the evidence of the alleged benefits? / ¿Cuáles son los beneficios $y$ las limitaciones identificados de SPC en el contexto de software, qué evidencias hay de los supuestos beneficios?

RQ3 Can SPG be applied to companies with lower levels of maturity or emerging companies? And what would be the conditions, settings, features, and environments to apply SPC in software processes? / ¿Se puede aplicar SPC a empresas con niveles de madurez menor o en empresas emergentes, cuáles serían las condiciones, los ajustes, las caracteristicas y los ambientes para aplicar SPC en los procesos software?

RQ4 What are the methodologies that support proper implementation of SPC in quantitative management? / ¿Cuáles son las metodologias que apoyan una adecuada implantación de SPC en la gestión cuantitativa?

RQ5 What activities and control methods are being proposed for monitoring software distributed processes in companies with lower levels of maturity or emerging ones? / ¿Qué actividades y métodos de control están siendo propuestas para el monitoreo de procesos software distribuidos en empresas con niveles de madurez menor o empresas emergentes?

contexto es fundamental encontrar el punto de partida para comprender si SPG se puede utilizar en el software y cómo.

Preguntas: En la TABLA 1, se indican las preguntas de investigación planteadas en esta revisión.

\subsection{Desarrollo del protocolo}

Para obtener la cadena de búsqueda se tuvo en cuenta las consideraciones de Kitchenham (2007).

Palabras clave y sinónimos. Statistical Process Control, Six Sigma, Quantitative Management, e ISO/TR 10017.

Intervención. Conocer, analizar y estudiar las técnicas del SPC, los cuadros de control y sus fundamentos, sus beneficios y limitaciones, para aplicar estas técnicas correctamente a la Ingeniería del Software. Conocer la aplicación de métodos que establezcan un seguimiento sistemático de diagnóstico de la estabilidad a través de un indicador de calidad de un proceso y de su capacidad para cumplir con especificaciones o límites de tolerancia y Six Sigma, los procesos de la ingeniería del software que requieren SPG y las métricas idóneas para procesos distribuidos SPC. Se identifica con términos de: gestión cuantitativa, Six Sigma y las técnicas estadísticas más conocidas en el reporte técnico (ISO, 2003).

Control. La revisión sistemática de Baldasarre, Caivano, Kitchenham, y Visaggio (2007), que condensa los gráficos del SPC más usados en la gestión cuantitativa de procesos software.

Resultado. Presentar el actual estado del arte con respecto de las experiencias e iniciativas propuestas por el SPG para la Ingeniería del Software, y llevar a cabo las actividades de investigación para el conocimiento de las técnicas del SPC y gestión cuantitativa aplicables e innovadoras para la Ingeniería del Software.

Población. Las experiencias e iniciativas propuestas de SPC que han sido aplicadas a la Ingeniería del Software y que han sido publicadas en la lista de fuentes. tation method, in order to articulate SPC to the management and, if possible, apply SPG to emerging companies. In this respect, it is essential to find the starting point to understand whether SPC can be used in the software and how.

Questions: In TABLE 1, the research questions raised in this review are indicated.

\subsection{Protocol development}

To obtain the search chain the considerations of Kitchenham (2007) were taken into account.

Keywords and synonyms. Statistical Process Control, Six Sigma, Quantitative Management, and ISO/TR 10017.

Intervention. To understand, analyze, and study the techniques of SPC, control charts, and fundamentals, its benefits and limitations, and to apply correctly these techniques to Software Engineering. To understand the application of methods to establish a systematic monitoring of diagnostic of the stability through a quality indicator of a process and its ability to meet specifications or tolerances and Six Sigma, the processes of software engineering that require $\mathrm{SPC}$ and appropriate metric for distributed $\mathrm{SPC}$ processes. This is identified with terms of quantitative management, Six Sigma, and the best known statistical techniques in the technical report (ISO, 2003).

Control. The systematical review of Baldasarre, Caivano, Kitchenham, and Visaggio (2007), which summarizes the most used SPC charts in quantitative management of software processes.

Result. Present the current state of the art regarding the experiences and initiatives proposed by the SPC to software engineering, and carry out research activities for the knowledge of SPC techniques, applicable quantitative management, and innovative software engineering.

Population. The experiences and SPG proposed initiatives that have been applied to software engineering and published in the source list.

Application. Those interested in using SPC in software engineering as a tool for quantitative management to measure and improve the overall quality.

Experimental design. Statistical techniques will not be applied to the primary studies but to the secon- 
dary ones for data synthesis, considering the control reference.

Definition of criterion for source selection. The sources have been identified on the basis of expert opinion in the workspace, which is the scope of the systematic review.

Language of the study. English.

Search method for sources. The execution of search results from primary sources will be conducted through web search engine SCOPUS.

Search chain. These were based on the questions. The result is the search string S1 detailed in TABLE 2.

Listed sources. Sources associated with Scopus: conferences, journals, conference proceedings, and book series, considering also contacting the authors, research groups, and experts.

\subsubsection{Protocol validation}

The SPG systematic review of Baldassarre, Caivano, Kitchenham, and Visaggio (2007) defines a control for the protocol, while others validate it. The validation is performed by following the protocol criteria of Brereton, Kitchenham, Budgen, Turner, and Khalil (2005), and the guidelines for systematic reviews of Kitchenham (2007) and Pino, Garcia, and Piattini (2007).

\subsection{Conducting the review}

\subsubsection{Source search process}

The search process is given by $\mathrm{S} 1$ search. SPC is among the 12 most known and used statistical techniques. SPC can be traced back to the 1920s as a technique used in the context of industrial production. Since then, plenty of literature has been produced. However, its application to software is very recent; the first paper about the application of SPC for software is by Gardiner and Montgomery (1987), which is considered the baseline.

Baldassarre, Boffoli, Caivano, and Visaggio (2004) suggest not sear-
Table 2. Search chain / Cadena de búsqueda

tions / Correspondencia a las preguntas

("statistical process control" OR [RQ1-RQ5]

"10017" OR "Six Sigma" OR "quan-

titative management")) AND ("sof-

tware engineering")
Aplicación. Las personas interesadas en el uso de SPC para la Ingeniería del Software como instrumento para la gestión cuantitativa en la medición y el mejoramiento de la calidad total.

Diseño experimental. No se aplicaran técnicas estadísticas a los estudios primarios, pero si a los estudios secundarios para la síntesis de datos, considerando la referencia de control.

Definición de los criterios de selección de las fuentes. Las fuentes han sido identificadas sobre la base de la opinión de expertos en el área de trabajo, que es el alcance de la revisión sistemática.

Lenguaje del estudio. Inglés

Método de búsqueda de las fuentes. La ejecución de búsqueda de los resultados de las fuentes primarias se llevará a cabo por medio de motores de búsqueda web: SCOPUS

Gadena de búsqueda. Fueron construidas con base en las preguntas. El resultado es la cadena de búsqueda S1 detallada en la TABLA 2.

Fuentes listadas. Fuentes asociadas a Scopus: conferencias, revistas, actas de conferencia, series de libros, teniendo en cuenta también, contacto con los autores, grupos de investigación y expertos.

\subsubsection{Validación del protocolo}

La revisión sistemática SPC de Baldasarre, Caivano, Kitchenham, y Visaggio (2007) define un control para el protocolo, mientras otras lo validan. La validación es llevada a cabo al se-
Table 3. Types of work in the search result / Tipos de trabajo resultado de la búsqueda

\begin{tabular}{lll}
\hline Detail / Detalle & Terms / Términos & Alternative terms / Términos alternativos \\
\hline Population / Población & $\mathrm{SE}$ & Software Engineering \\
Main intervention / & $\mathrm{SPC}$ & $\begin{array}{l}\text { Statistical process control, Six Sigma, quantitative ma- } \\
\text { Intervención principal }\end{array}$
\end{tabular}

Results / Resultados Type of work in the Software engineering, Statistical process control, Quaresearch result with lity control, Computer aided software engineering, its attributes to ex- Computer software, Quality assurance, Project matract. / Tipos de trabajo nagement, Mathematical models, Statistical methods, resultado de la búsqueda con Process control, Standards, Computer software selecsus atributos a extraer tion and evaluation, Six Sigma, Data reduction, Total quality management, Control charts, Optimization, Productivity, Strategic planning, Computer software maintenance, Customer satisfaction, Industrial management, Software industry, Software quality, Competition, Database systems, Decision-making, Information management, Inspection, Product design, Quality function deployment, Software metrics, Algorithms, Data acquisition, Failure analysis, Personnel training. 


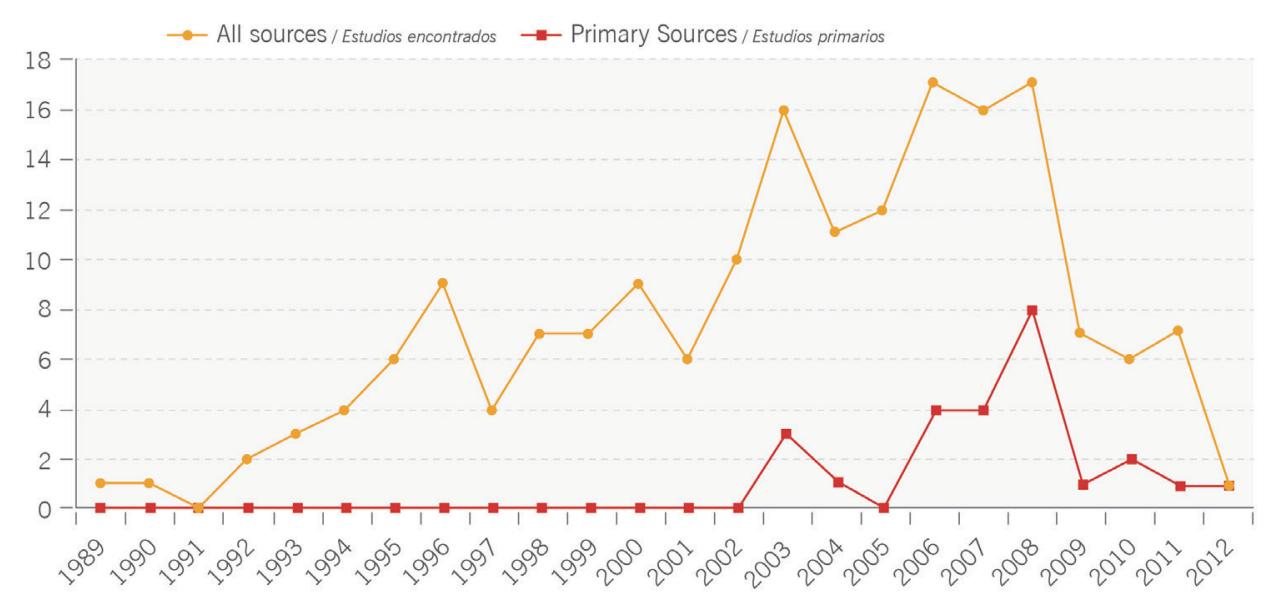

Figure 2. Trend sources of search S1 and selected sources for extraction / Tendencia de fuentes de la búsqueda S1 y fuentes seleccionadas para la extracción ching articles published before 1987. In response to this recommendation, the searched documents concerning SPG for software processes range between 1989 and 2012. The search results associated S1 yielded 179 sources in digital libraries linked to Scopus: university digital libraries, printed editions of ACM, IEEE, Sprin- guir los criterios del protocolo que presentan Brereton, Kitchenham, Budgen, Turner, y Khalil (2005), y las directrices para las revisiones sistemáticas que presentan Kitchenham (2007) y Pino, García, y Piattini (2007).

\subsection{Conduciendo la revisión}

\subsubsection{Proceso de búsqueda de las fuentes}

$\mathrm{El}$ proceso de búsqueda está dado por la búsqueda S1. Se encuentra a SPC entre las doce técnicas estadísticas más conocidas y utilizadas. SPC se remonta a los años 20 como una técnica utilizada en el contexto de la producción industrial. Desde entonces, se ha producido bastante literatura al respecto. Sin embargo, su aplicación al software es muy reciente, el primer documento sobre la aplicación SPC para el software es de Gardiner y Montgomery (1987), documento que se considera, la línea base.

Baldassarre, Boffoli, Caivano, y Visaggio (2004) sugieren no buscar artículos publicados antes de 1987. Atendiendo esta recomendación, los documentos de las búsquedas del SPG para procesos software oscilan entre 1989 y 2012. El resultado de la búsqueda asociada S1 arrojó un total de 179 fuentes, en librerías digitales asociadas a Scopus, en bibliotecas digitales universitarias, en ediciones impresas - de ACM, IEEE, Springer, Crosstalk, Elservier, Alfa Omega, etc.), y en publicaciones comerciales, revistas, actas de conferencia y series de libros.

En este orden de ideas, la lista de fuentes primarias asociadas a la investigación parte de 2002. La Figura 2 muestra una tendencia de todas las fuentes listadas por la búsqueda $\mathrm{S} 1$; y una tendencia de las fuentes para la extracción seleccionadas como fuentes primarias.

\subsubsection{Selección estudios primarios: criterios de inclusión y exclusión}

La fase de selección consistió en identificar las fuentes primarias de las fuentes de la búsqueda por los criterios de inclusión y exclusión para llegar al conjunto de publicaciones adecuadas de donde serán tomados los datos para la extracción. A continuación, el proceso de selección es dividido en dos partes, finalizando con la síntesis de datos:

Griterios de inclusión. El siguiente paso fue seleccionar los estudios primarios en función de los criterios inclusión. Pri- ger, Crosstalk, Elsevier, Alpha Omega, etc., andcommercial publications, magazines, conference proceedings, and series books.

The list of primary sources related to the investigation starts from 2002. Figure 2 shows a tendency of all sources listed by the search S1, and a tendency of sources for extraction selected as primary sources.

\subsubsection{Selection of primary studies: inclusion and exclusion cri-} teria.

The selection phase consisted of identifying the primary sources of the search sources using the criteria of inclusion and exclusion to reach the set of appropriate publications from which the data for the extraction could be taken. Consequently, the selection process was divided into two parts, ending with data synthesis.

Inclusion criterion. The next step was to select primary studies according to the inclusion criterion. First, the title, publication year, and keywords were recognized, to exclude those sources that seemed totally irrelevant. If there was no certainty in this scan, the abstracts were read. The inclusion of the documents in this review refers mainly to the fact that the simplest information will present: concepts, tools, and techniques of SPC and statistical foundations necessary for its quantitative application of software processes. In particular, theoretical works are included that discuss SPG techniques in the context of software processes, empirical studies that incorporate real data analysis of software processes, documents that expose a theoretical and empirical content of application methods and implementation of SPC to software. As a result, 11 duplicate documents were removed and 78 relevant studies selected. 


\section{Exclusion criterion.}

From the relevant sources an exploration of content and reading the introduction and conclusions was performed to ensure that the exclusion criterion was met. Documents that discussed methods to control software development using measurements that do not explicitly include the SPC as quantitative management technique were excluded, as well as documents that do not respond to the application of SPC to software production, and documents and reports that are just a summary or PowerPoint presentation. Twenty five documents were selected as primary studies, which are listed and stored along with the information that could have been accessed, and the most important ideas of the study registered.

\subsubsection{Study for assessing the quality and data extraction}

For information extraction the quality of primary studies is estimated by examining the entire document. The quality of the sources is evaluated by attributes (R1, ..., R5) (TABLE 4).

The quality assessment is introduced as criterion for inclusion/exclusion, with verification of the selection criteria, giving quality attributes to documents on a scale range of $[0,1]$, as shown in TABLE 5. Quality assessment allows for the detailed recognition of information sources, distinguishing the nature of the document (theoretical or empirical) and evaluating it against the research questions to extract the necessary information.

The inclusion/exclusion criteria result in primary studies which refer to the search chain S1. Many documents did not meet the inclusion criteria. This gene- mero se reconoció el título, la publicación, el año y las palabras clave, para excluir aquellas fuentes que parecían totalmente irrelevantes. Si en este escaneo no había certeza, se leían los resúmenes. La inclusión de los documentos en esta revisión se refiere principalmente a que la información más sencilla presentara: conceptos, herramientas y técnicas del SPC y fundamentos estadísticos necesarios para su aplicación cuantitativa de procesos software. En particular, se incluyen: trabajos teóricos que discutían las técnicas del SPG en el contexto de los procesos software; trabajos empíricos que incluyen el análisis de datos reales en procesos de software, los documentos que exponen un contenido teórico y empírico de métodos de aplicación e implantación de SPC al software. Como resultado se eliminaron once documentos duplicados y se seleccionaron 78 estudios relevantes.

Griterios de exclusión. De las fuentes relevantes se realizó una exploración del contenido y la lectura de la introducción y las conclusiones para asegurar que cumplían con los criterios de exclusión. Se excluyeron los documentos que discutían métodos para controlar el desarrollo de software usando mediciones que no incluyen explícitamente el SPC como técnica de la gestión cuantitativa; documentos que no responden a la aplicación del SPC para la producción de software; y documentos e informes que sólo son un resumen o una presentación de

Table 5. Quality assessment of study document $N^{\circ} 6$ / Evaluación de la calidad del documento de estudio $N^{\circ} 6$

\begin{tabular}{|c|c|c|c|c|c|c|c|c|c|}
\hline \multirow{2}{*}{$\begin{array}{l}\text { Study } \\
\text { Estudio }\end{array}$} & \multirow{2}{*}{ Title / Titulo } & \multirow{2}{*}{ Authors / Autores } & \multirow{2}{*}{ Year / Año } & \multirow{2}{*}{ Library / Biblioteca } & \multicolumn{5}{|c|}{ Questions / Preguntas } \\
\hline & & & & & R1 & R2 & R3 & R4 & R5 \\
\hline 6 & $\begin{array}{l}\text { BSR: A Statistic-based } \\
\text { Approach for Establi- } \\
\text { shing and Refining Sof- } \\
\text { tware Process Perfor- } \\
\text { mance Baseline }\end{array}$ & $\begin{array}{l}\text { Qing Wang, Nan } \\
\text { Jiang, Lang Gou, } \\
\text { Xia Liu, Mingshu } \\
\text { Li, Yongji Wang }\end{array}$ & 2006 & $\begin{array}{l}\text { IRISA (Institut de re- } \\
\text { cherche en informati- } \\
\text { que et systèmes aléa- } \\
\text { toires) }\end{array}$ & 1 & 1 & 1 & 1 & 0 \\
\hline
\end{tabular}


Table 6. Register form for the extraction of study document $N^{\circ} 6$ / Formato de registro para la extracción del documento de estudio $N^{\circ} 6$

\begin{tabular}{|l|l|}
\hline No 6 & BSR: A Statistic-based Approach for Establishing and Refining Software Process Performance Baseline \\
\hline Name / Nombre & 28th International Conference on Software Engineering (ICSE'06) \\
\hline Type of document / Tipo de documento & 2006 \\
\hline Date / Fecha & Qing Wang, Nan Jiang, Lang Gou, Xia Liu, Mingshu Li, Yongji Wang \\
\hline Authors / Autores &
\end{tabular}

Objective results of the study / Resultados Objetivo del Estudio

\begin{tabular}{|c|c|c|}
\hline \multicolumn{2}{|c|}{ Methodology / Metodología } & Empirical validation / Validación empírica \\
\hline \multicolumn{2}{|c|}{ Output / Salida } & $\begin{array}{l}\text { Identify quantitative objectives of the process, determine process stability, data processing and characte- } \\
\text { rization of the process, raises a method to refine the baseline in behavior of the software process for the } \\
\text { quantitative management effectiveness. / Identifica objetivos cuantitativos del proceso, determinan estabilidad del proceso, tratamiento de los } \\
\text { datosy caracterización del processo, propone método para refinar la linea base en el comportamiento del proceso soffweare para la efectividad en la gestión cuantitativa. }\end{array}$ \\
\hline \multicolumn{2}{|c|}{ Country / País } & Shanghai, China \\
\hline \multirow[t]{5}{*}{$\mathrm{R} 1$} & $\begin{array}{l}\text { Theorical concepts / Conceptos } \\
\text { teóricos }\end{array}$ & $\begin{array}{l}\text { Median }(\mu) \text {, standard deviation }(\sigma) \text {, Pareto chart, cause - effect chart and the scatterplot. / media ( }(\mu) \text {, desviación } \\
\text { estándar }(\sigma) \text {, diagrama de Pareto, diagrama de causa - efecto y el gráfico de dispersión (Scatter) }\end{array}$ \\
\hline & $\begin{array}{l}\text { Process softwarea activity / } \\
\text { Actividad del proceso software }\end{array}$ & $\begin{array}{l}\text { 1. Development and review of the requirements stability code } 2 \text {. Requirements stability / 1. Desarrollo y revisión } \\
\text { de código estabilidad de los requisitos. 2. Estabilidad de los requisitos }\end{array}$ \\
\hline & Metrics / Métricas & $\begin{array}{l}\text { 1.1. Schedule. RSV: Relation of the Schedule variation of the work., 1.2 Quality. MDD: Module defect } 2 . \\
\text { Requirements stability. RCR: Requirements rate of change. / 1.1. Calendario. RSV: Relación de la variación del calendario } \\
\text { de la tarea, 1.2 Calidad. MDD: Densidad de defectos del módulo 2. Estabilidad de los requisitos. RCR: Razón de cambio de los requisitos }\end{array}$ \\
\hline & Type of chart / Tipo de gráfico & 1.1 XmR chart 1.2. Ghart Z 2. Chart $\mathrm{P} / 1.1 \mathrm{XmR}$ chart 1.2. Grafico Z2. Gráfico $P$ \\
\hline & $\begin{array}{l}\text { Data distribution / Distribución } \\
\text { de los datos }\end{array}$ & $\begin{array}{l}\text { 1.1 Normal distribution 1.2 Poisson distribution 2. Binomial distribution / 1.1 Distribución normal 1.2 Distribución } \\
\text { de Poisson 2. Distribución Binomial }\end{array}$ \\
\hline \multirow[t]{2}{*}{$\mathrm{R} 2$} & Limitations / Limitaciones & $\begin{array}{l}\text { The performance of software processes do not dependent on the equipment for online production, it de- } \\
\text { pends on the people running the process. Different people or equipment have different performance and } \\
\text { ability to even use the same device. It is difficult to establish precisely the base line of the software process. } \\
\text { Many researchers try to make a comparison with industrial processes for the implementation of quanti- } \\
\text { tative management techniques. I El rendimiento de los procesos softurare no depende de equipo para la producción en linea, sino que depende } \\
\text { de las personas que ejecutan el proceso. Diferentes personas o equipos tienen diferentes rendimiento y capacidad de incluso usar el mismo dispositivo. La linea } \\
\text { base del proceso de software es dificil de establecer con precisión. Muchos investigadores tratan de establecer una comparación con los processos industriales para } \\
\text { la aplicación de técnicas de gestión cuantitativa. }\end{array}$ \\
\hline & Benefits / Beneficios & $\begin{array}{l}\text { It is an effective method to establish the process and the improvement of the quantitative management of pro- } \\
\text { cesses and organizations with low levels of maturity, can identify weaknesses in the process. / Es un método efectivo para } \\
\text { establecer el proceso y el mejoramiento de la gestión cuantitativa de los procesos y organizaciones con bajo nivel de madurez, permite identificar las debilidades del proceso. }\end{array}$ \\
\hline R3 & $\begin{array}{l}\text { Standard process maturity / } \\
\text { Madurez del proceso/ estándar }\end{array}$ & $\begin{array}{l}\text { Lower or higher of CMMI Level 3. The organization must define its processes and select some of them to } \\
\text { improve the quality and characteristics that must be measured. They use the Run Chart to obtain infor- } \\
\text { mation about process improvement when the process is at low level and is unstable. / Menor o mayor de CMMI } \\
\text { Level3. La organización debe definir sus procesos y seleccionar algunos de ellos para el mejoramiento de la calidad y caracteristicas que deben medirse. Utilizan } \\
\text { del gráfico Run Chart para obtener información de mejoras del proceso cuando el proceso está en bajo nively es inestable. }\end{array}$ \\
\hline $\mathrm{R} 4$ & $\begin{array}{l}\text { SPC applied methods / Méto- } \\
\text { dos aplicados SPC }\end{array}$ & Raises the BSR (Baseline-Statistic-Refinement) / Propone el BSR (Baseline-Statistic-Refinement) \\
\hline R5 & $\begin{array}{l}\text { Distributed processes manage- } \\
\text { ment methodologies. / Metodologías } \\
\text { de Gestión procesos distribuidos }\end{array}$ & Does not apply. / No aplica \\
\hline \multicolumn{3}{|c|}{ Subjetive results of the study / Resultados subjetivos del estudio } \\
\hline \multicolumn{3}{|c|}{$\begin{array}{l}\text { Based on data, the exceptional point is analyzed to find and eliminate the exceptional cause. Statistical methods such as Pareto chart, diagram } \\
\text { cause - effect, and the scatter plot are useful. A Pareto chart is a bar frequency table in descending order; frequency bars are usually associated with } \\
\text { the types or causes of problems. When organizing causes based on frequency of problems, a Pareto chart can identify the few causes that account } \\
\text { for most of the problems. Indicating that problems should be solved first in the processes improvement. The Pareto analysis commonly refers } 80: 20 \\
(20 \% \text { of causes represents } 80 \% \text { of the problems). This helps to identify areas that cause the most problems, which usually means getting the best } \\
\text { return on investment when they are arranged. / Basándose en los datos, el punto excepcional es analizado para encontrar y eliminar la causa excepcional. Métodos estadisticos como el diagrama } \\
\text { de Pareto, diagrama de causa - efecto, y el gráfico Scatter de dispersión son útiles. Un diagrama de Pareto es una tabla de frecuencias de barras en orden descendente; las barras de frecuencia suelen asociarse a los tipos } \\
\text { o causas de los problemas. Al organizar las causas basadas en frecuencia de problemas, un diagrama de Pareto puede identificar las pocas causas que representan la mayoria de los problemas. Indicando que problemas } \\
\text { deben resolverse primero en el mejoramiento de procesos. Los Análisis de Pareto referen comminmente } 80: 20 \text { (20\% de las causas representan el } 80 \% \text { de los problemas). Esto ayuda a identificar las áreas que causan la } \\
\text { mayoría de los problemas, que normalmente significa obtener el mejor retorno de inversión cuando se arreglan. }\end{array}$} \\
\hline
\end{tabular}


rated the identification of 25 sources including conference proceedings, journal articles, conference papers, and books that provide a current status of SPC and its application to advanced quantitative management software processes.

\subsubsection{Results from extraction}

The results of the quality assessment allow to distinguish the nature of the document and the information that answers the research questions (RQ1, RQ2, ... RQ5). The information of the primary studies that approves the attribute (R1, R2, .. R5) is extracted to a registration form for each of the primary studies.

Registration form for the extraction. The format is structured with the following rows: number, name, document type (conference proceedings, conference, magazine publishing, book, monograph), date, author, country; Results of the study: methodology followed (theoretical, empirical validation, case study); if applies to R 1 theoretical approach: SPC techniques in software, statistical foundations, concepts and techniques that complement it; used control charts; processes capacity concept and Six Sigma, metrics, entities that can be measured with SPG in the software process; if applies to R2, benefits and limitations of SPC, SPC empirical validation in software; if applies to R3 study cases of SPC applied in measuring process with CMMI $<4$ or emerging organizations and process requirements as pre stage to apply SPC; if applies the SPC implementation to the process, monitoring methods, anomalies, stability tests, and settings; Six Sigma management methodology, R5 Study cases of the software quantitative management in organizations with distributed processes, organizational level, application of SPC in software process improvement and project management processes. The TABLE 6 shows the format for document No. 6.

Data synthesis. The results of the evaluation indicate the correspondence of the document to the questions, showing the status of the topic of interest. The extraction and synthesis of data will be communicated in a document that permits to conclude the current state of SPG software processes. This paper presents a first report of results from 25 primary sources, of which 56\% are lectures, 24\% journal articles, 8\% monographs, 8\% books, and 4\% Acts of Congress (Figure 3).

The assessment determines the proportion of documents that answers the research questions for data extraction (Figure 4).
PowerPoint. Resultaron seleccionados 25 documentos como estudios primarios, los cuales son enumerados y guardados, junto con la información a la que se ha tenido acceso, las ideas más importantes del estudio son registradas.

2.3.3 Estudio para la evaluación de la calidad y extracción de los datos

Para la extracción de la información se estima la calidad de los estudios primarios, examinando el documento en su totalidad. La calidad de las fuentes es evaluada por los atributos (R1,.., R5), (TABLA 4).

Se introduce la evaluación de la calidad como criterio de inclusión / exclusión, con la verificación de los criterios de selección, dando atributos de calidad a los documentos en una escala de rango de $[0,1]$, como se observa en la TABLA 5 . La evaluación de la calidad permite el reconocimiento detallado de la información de las fuentes, distinguiendo la naturaleza del documento (teórico o empírico) y evaluando frente a las preguntas de la investigación para extraer la información necesaria.

Los resultados de los criterios de inclusión / exclusión dan como resultado los estudios primarios que hacen referencia a la cadena de búsqueda S1. Muchos documentos no satisfacían los criterios de inclusión. El resultado genera la identificación de 25 fuentes entre actas de congreso, artículos en revistas, conferencias, monografías y libros, que permiten obtener un estado actual del SPC y de su aplicación a la gestión cuantitativa avanzada de procesos software.

\subsubsection{Resultados de la extracción}

Los resultados de la evaluación de la calidad permiten distinguir la naturaleza del documento y la información que responde a las preguntas de la investigación (RQ1, RQ2,... RQ5). La información de los estudios primarios que aprueba el atributo (R1, R2,...R5) es extraída a un formato de registro para cada uno de los estudios primarios.

Formato de registro para la extracción. El formato se estructura con las siguientes filas: número, nombre, tipo de documento (acta de congreso, conferencia, publicación de revista, libro, monografia), fecha, autor, país; Resultados del estudio: metodología seguida (teórica, validación empírica, caso de estudio); si aplica a R1 Enfoque teórico: técnicas de SPC en software, fundamentos estadísticos, conceptos y técnicas que lo complementan; gráficos de control usados; concepto de capacidad de procesos y Six Sigma, métricas, entidades que pueden ser objeto de medición con SPC en el proceso software; si aplica a R2 Beneficios y limitaciones de SPC, validaciones empíricas de SPC en software; si aplica R3 casos de estudio de SPG aplicado en la medición de proceso con CMMI $<4 \mathrm{u}$ organizaciones emergentes y requisitos del proceso como pre etapa ara aplicar SPC; si aplica a implantación de SPC al proceso, métodos de monitoreo, anomalías, test de estabilidad y ajustes; metodología de gestión Six Sigma, R5 Casos de estudio de la gestión cuantitativa software en organizaciones con procesos distribuidos, nivel de la organización, aplicación de SPC en la mejora del proceso software y la gestión del proyecto. La TABLa 6 muestra el formato para el documento $\mathrm{N}^{\circ} 6$.

Síntesis de datos. Los resultados de la evaluación indican la correspondencia del documento con las preguntas, eviden- 


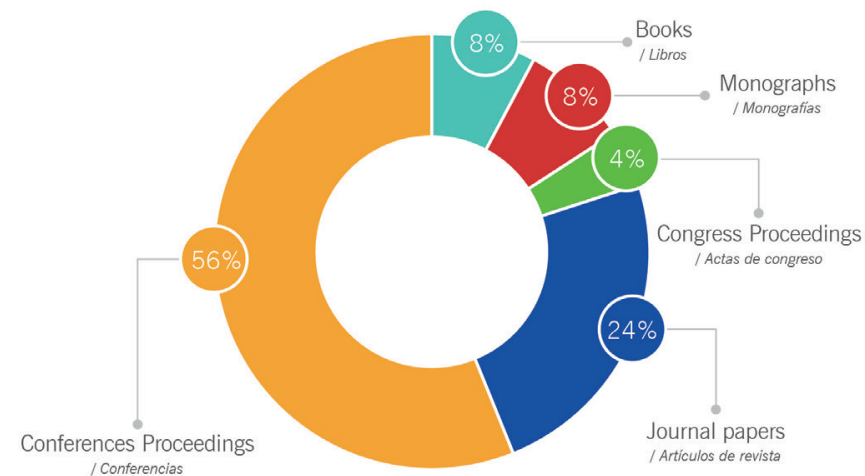

Figure 3. Percentage of the type of documents / \% del tipo de documentos

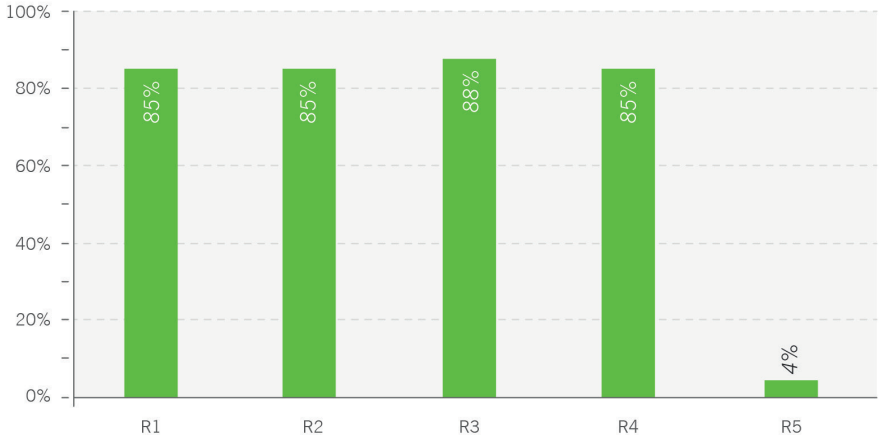

Figure 4. Correspondence percentage of sources for information extraction / \% Correspondencia de fuentes para la extracción de la información

\subsubsection{Documentation of the review}

This paper presents a first report of results from 25 primary sources, of which $56 \%$ are lectures, $24 \%$ journal articles, $8 \%$ monographs, $8 \%$ books, and $4 \%$ Acts of Congress (see Figure 3).

The assessment permits to determine the proportion of documents that answers research questions for data extraction (FIGURE 4).

Below, a synthesis of the obtained main results that permit answering the research questions is provided:

For RQ1: What are the initiatives and experiences of SPG in Software Engineering, the SPG control charts being used, statistical techniques, and addressed tools to complement its implementation?

$\mathrm{R} 1$ classifies in $85 \%$ of the documents which present initiatives and experiences of SPC techniques in software, metrics, and entities that can be measured with SPC in the software process. They also contain: theoretical basis for the SPC, and present the basic definitions and concepts; the statistical foundations of average, median, mode, range, standard deviation, variance, normal distribution, and central limit theorem; the techniques of statistical process control [SPC]; the variability by common causes and assignable causes; support tools for statistical control (data types, types of control charts); process capability and potentiality; and the concept of Six Sigma metrics.

These documents, which evidence the experiences of SPC application in software, permit to synthesize data to determine the type of control charts that are used in the software cycle processes where SPC has been applied.

It is determined that the top three processes of the development cycle that mostly use SPC techniques applying control charts are the development and code review with $27 \%$, followed by the testing process, design, and

ión ción SPC en software permiten sintetizar datos para determi- 


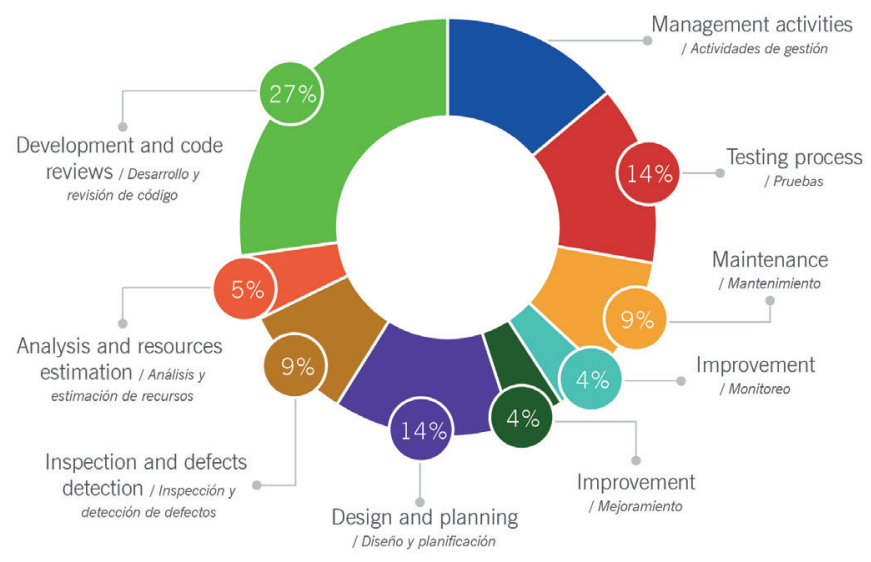

Figure 5. Percentage of software Engineering processes as object of measurement with SPC / \% de procesos de ingeniería del software objeto de medición con SPC

planning (14\%), and management undefined activities (14\%); while processes such as maintenance, inspection, and detection of defects account for 9\% each (FIGURE 5).

Data provided by the control systematic review as a reference for comparison with the data obtained is considered. It can be seen in TABLE 7 that the process of development and code review preceded the testing process in the application of SPC.

In the context of control charts, the documents are evidence of the most used type of charts: XmR (44\%); Xbar R chart, c chart, $\mathrm{u}$ chart, and $\mathrm{z}$ chart are also applied (around 13\% each), as shown in Figure 6.

When considering the data provided by the control systematic review as reference of comparison with the obtained data, it appears that the $\mathrm{XmR}$ graph remains the most applied (see TABLE 8).

To Baldassarre, Boffoli, Caivano, and Visaggio, (2004), according to the contributions of the literature, the interest in the use of SPG in the context of software focuses on: applications in inspection and review, testing, maintenance, and personal software process. Other contributions have successful results of the use of SPC in the context of software, however, they do not show a clear understanding of the meaning of control charts in the context of the application in software processes.

The SPC in software requires choosing the critical processes for its application, considering that it is possible to control and improve the quality of primary processes by measuring the support processes (Manlove \& Khan, 2007).

For the choice of the chart, in the theoretical model of $\mathrm{SPC}$, much of the data in the appropriate conditions can have a binomial distribution, Poisson or normal. From

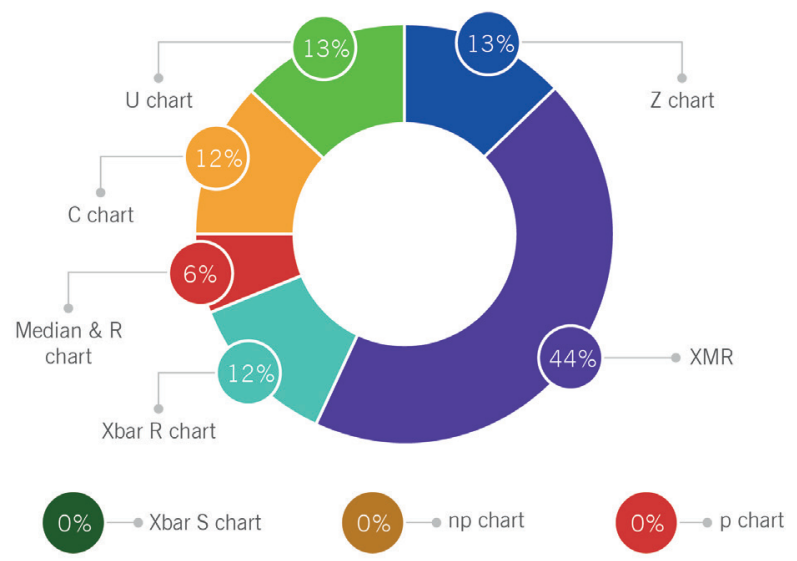

Figure 6. Percentage of control charts used in software processes / $\%$ Gráficos de control usados en los procesos software

Table 7. Processes object of measurement / Procesos objeto de Medición con SPC

\begin{tabular}{lll}
\hline $\begin{array}{l}\text { Processes object of mea- } \\
\text { surement / Proceso objeto de medición }\end{array}$ & $\mathbf{1 . \text { Control }}$ & $\begin{array}{l}\text { 2. Sources } \\
\text { / 2. Fuentes }\end{array}$ \\
\hline Tests / Pruebas & $26 \%$ & $14 \%$ \\
$\begin{array}{l}\text { Inspection and defects detec- } \\
\text { tion / Inspección y detección de defectos }\end{array}$ & $6 \%$ & $9 \%$ \\
$\begin{array}{l}\text { Improvement / Mejoramiento } \\
\text { Monitoring / Monitoreo }\end{array}$ & $6 \%$ & $5 \%$ \\
$\begin{array}{l}\text { Design and planning / Diseño y } \\
\text { planeación }\end{array}$ & $13 \%$ & $5 \%$ \\
$\begin{array}{l}\text { Maintenance / Mantenimiento } \\
\text { Analysis and resources estima- } \\
\text { tion / Análisis y estimación de recursos }\end{array}$ & $9 \%$ & $14 \%$ \\
$\begin{array}{l}\text { Development and code review } \\
\text { / Desarrollo y revisión de código }\end{array}$ & $19 \%$ & $9 \%$ \\
$\begin{array}{l}\text { Management activities (undefi- } \\
\text { ned) / Otras actividades de gestión }\end{array}$ & $6 \%$ & $27 \%$ \\
\hline
\end{tabular}

Table 8. Percentage of used control charts / \% Gráficos de control usados

\begin{tabular}{lll}
\hline Chart / Tipo de gráfico & 1. Control & $\begin{array}{l}\text { 2. Sources / } \\
\text { 2. Fuentes }\end{array}$ \\
\hline XmR & $37 \%$ & $44 \%$ \\
Xbar R chart & $8 \%$ & $13 \%$ \\
Median \& R chart & $4 \%$ & $6 \%$ \\
X-bar S chart & $13 \%$ & $0 \%$ \\
C chart & $0 \%$ & $13 \%$ \\
U chart & $17 \%$ & $13 \%$ \\
np chart & $4 \%$ & $0 \%$ \\
p chart & $0 \%$ & $0 \%$ \\
z chart & $4 \%$ & $13 \%$ \\
None / Ninguno & $13 \%$ & $0 \%$ \\
\hline
\end{tabular}

nar el tipo de gráficos de control que son usados en los procesos del ciclo de software donde se ha aplicado SPC. 


\begin{tabular}{|c|c|c|c|c|c|c|c|c|c|}
\hline $\begin{array}{l}\text { Chart/SP / Tipo de grá- } \\
\text { fico/SP }\end{array}$ & 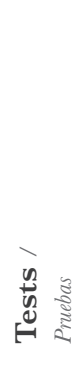 & 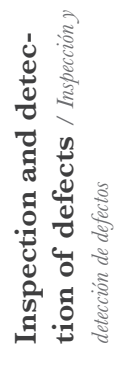 & 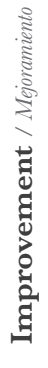 & 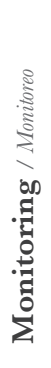 & 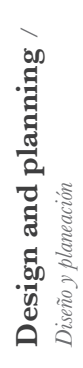 & 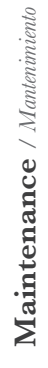 & 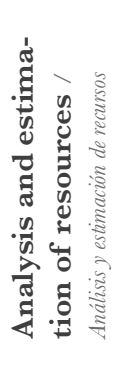 & 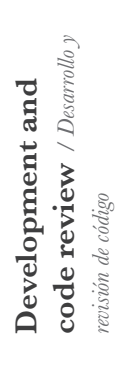 & 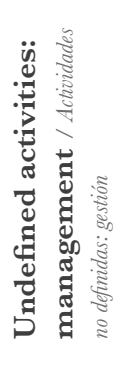 \\
\hline $\mathrm{XmR}$ & $\mathrm{X}$ & $\mathrm{X}$ & $\mathrm{X}$ & $\mathrm{X}$ & $\mathrm{X}$ & $\mathrm{X}$ & $\mathrm{X}$ & $\mathrm{X}$ & $\mathrm{X}$ \\
\hline Xbar R chart & & & & & $\mathrm{X}$ & & & & \\
\hline Median \& R chart & & & & & & & & $\mathrm{X}$ & $\mathrm{X}$ \\
\hline X-bar S chart & & & & & & & & & $\mathrm{X}$ \\
\hline C chart & & & & & & & & $\mathrm{X}$ & \\
\hline $\mathrm{U}$ chart & $\mathrm{X}$ & $\mathrm{X}$ & & & & & & & $\mathrm{X}$ \\
\hline $\mathrm{z}$ chart & $\mathrm{X}$ & & & & & & & $\mathrm{X}$ & \\
\hline
\end{tabular}

Se obtiene que entre los tres primeros procesos del ciclo de desarrollo que más usan las técnicas SPC aplicando los gráficos de control, están el desarrollo y revisión de código con un $27 \%$, seguido de los procesos de prueba, diseño y planeación, y actividades no definidas de la gestión, cada uno con $14 \%$; mientras procesos como el mantenimiento e inspección y detección de defectos representan el 9\% cada uno, (Figura 5).

Se considera los datos ofrecidos por la revisión sistemática de control como referencia de comparación con los datos obtenidos. Ver la TABLA 7 , donde se encuentra que el proceso de desarrollo y revisión de código ha precedido al proceso de pruebas en la aplicación de SPC.

En el contexto de los gráficos de control, los documentos evidencian como tipos más utilizados: el XmR en un 44\%, el Xbar R chart, c chart, u chart y z chart son igualmente aplicados en un 13\% cada uno, (ver Figura 6).

$\mathrm{Al}$ considerar los datos ofrecidos por la revisión sistemática de control como referencia de comparación con los datos obtenidos, se evidencia que el gráfico $\mathrm{XmR}$ sigue siendo el más aplicado, ver TABLA 8.

Para Baldassarre, Boffoli, Caivano, y Visaggio, (2004), de acuerdo con las contribuciones de la literatura, el interés por el uso de SPG en el contexto del software se enfoca a: aplicaciones en la inspección y revisión, las pruebas, el mantenimiento, el proceso de software personal. Otras contribuciones presentan resultados exitosos del uso de SPG en el contexto del software, sin embargo, no muestran una clara comprensión acerca del significado de los gráficos de control en el contexto de la aplicación en procesos de software.

El SPC en software requiere elegir los procesos críticos para su aplicación, considerando que es posible controlar y mejorar la calidad de los procesos primarios midiendo los de apoyo (Manlove \& Kan, 2007).

Para la elección del gráfico, dentro del modelo teórico a practical point of view, depending on the type of data, Binomial and Poisson distribution are of considerable interest because they help to discriminate the choice of control charts. However, for Ferreiro (2010) control charts are based on the properties of the normal curve for two basic purposes: to show whether a process has been operating under statistical control and to point out the presence of special causes of variation which must be corrected as they are presented; to allow maintaining the state of statistical control, since you can make decisions based on process performance over time.

Depending on the quality characteristic to control and according to the type of data, control charts are divided into two groups: control charts for variables and control charts for attributes.

According to Weller (2000), the most used charts in software processes are the control chart for single variables and moving range, i.e. $\mathrm{XmR}$, due to the scarcity of data, since measurements often occur only as individual values.

Komuro (2006) argues that the management of individual data becomes more important in the use of control charts and concludes that the $\mathrm{XmR}$ is more useful than ever, while $\mathrm{X}$-bar-R seems to be ineffective; since it is difficult to obtain a large homogenous data set in software development, charts which can register individual data are more useful. Therefore, XmR, Z or U-graphics are adequate. Moreover, the bar chart XR, which was the most popular chart in Total Quality Management [TQM], seems to be inadequate in software development processes, as it usually assumes the 
size of the subgroups as constant. X-bar-S can be applied for the analysis of effects because it can be used either with a variable size of subgroups and has bound of control more accurate than Xbar-R.

Some studies in which can be observed cases of application of control charts for software processes are: Wang et al. (2006), Card, Domzalski, and Davies (2008), Hale and Row (2012), Salin, Monteiro, and Marcal de Oliveira (2009), Wang, Gou, Jiang, and Che (2007), Tarhan and Demirörs (2008), Alzate and Molina (2009), Xiaosong, Zhen, Fangfang, and Shenqi (2008), and Boffoli, Bruno, Caivano, and Mastelloni (2008).

Among the studies in which can be observed cases of application of control charts to software processes are those of Wang et al. (2006), Card, Domzalski, and Davies (2008), Hale and Row (2012), Salin, Monteiro, and Marcal de Oliveira (2009), Wang, Gou, Jiang, and Che (2007), Tarhan and Demirörs (2008), Alzate and Molina (2009), Xiaosong, Zhen, Fangfang, and Shenqi (2008), and Boffoli, Bruno, Caivano, and Mastelloni (2008).

\section{For RQ2: What are the benefits and limitations} of SPC identified in the context of software, and the evidence of the supposed benefits?

$\mathrm{R} 6$ responds with $85 \%$ of the documents to the benefits and limitations of SPC, SPC empirical validation in software.

Most of the acquired knowledge about SPC to software processes is given by analogy with other disciplines and some experiences of its application in these processes, despite the difficulties in its implementation. According to Komuro (2006), there is evidence that the SPC has positive effects on product quality, making it necessary to focus more on the processes than on the product.

For Manlove et al. (2007), implementation of SPC in software processes is logically commented, but this is problematic in practice for several reasons: the software is produced by people, not machines; there are significant sources of variability within software development environment that can be difficult to minimize or control, i.e., there are multiple causes; indicators of the process behavior vary with the development cycle; and most software measurement data were not normally distributed.

Critical issues for the successful implementation of SPC are: process stability, measurement capability, and reliability of the data, in other words, if the process has been standardized, the right metrics have been selected, and a reliable de SPC, muchos de los datos en las condiciones adecuadas pueden tomar una distribución binomial, de Poisson o normal. Desde un punto de vista práctico, según el tipo de datos, la distribución Binomial y la de Poisson son de considerable interés ya que ayudan a discriminar en la elección de gráficos de control. Sin embargo, para Ferreiro (2010) los gráficos de control están basados en las propiedades de la curva normal para dos usos básicos: evidenciar si un proceso ha estado operando bajo control estadístico y señalar la presencia de causas especiales de variación, que deben ser corregidas en cuanto se presenten; y permitir mantener el estado de control estadístico, ya que se puede tomar decisiones con base en el comportamiento del proceso a lo largo del tiempo.

Dependiendo de la característica de calidad por controlar y de acuerdo con el tipo de datos, los gráficos de control se dividen en dos grandes grupos: gráficos de control por variables y gráficos de control por atributos.

Según Weller (2000) los gráficos más utilizados en los procesos de software son el grafico de control por variables individual y rango móvil, es decir $\mathrm{XmR}$, debido a la escasez de datos, desde que las mediciones a menudo se producen sólo como valores individuales.

Para Komuro (2006) el manejo de datos individuales se vuelve más importante en el uso de grafios de control y concluye que el XmR es más útil que nunca, mientras que $\mathrm{X}$-bar-R parece ser inútil, puesto que es difícil obtener un gran conjunto de datos homogéneos en desarrollo de software, los gráficos en los que se pueden trazar datos individuales son más útiles. Así, XmR, Z o U-gráficos son los adecuados. Por otra parte, el gráfico de barras X-R, que era el gráfico más popular de todos en Gestión Total de la Calidad [TQM], parece ser inútil para procesos de desarrollo de software, ya que por lo general asume como constante el tamaño de los subgrupos. X-bar-S se puede aplicar para el análisis de efecto porque se puede utilizar bien con un tamaño variable de subgrupos y tiene límite de control más exacto que Xbar-R.

Entre los estudios donde pueden observarse casos de aplicación de los gráficos de control a procesos software se encuentran los de: Wang et al., (2006); Card , Domzalski, y Davies (2008), Hale y Row (2012), Salin, Monteiro, y Marcal de Oliveira (2009), Wang, Gou, Jiang, y Che (2007), Tarhan y Demirörs (2008), Alzate y Molina (2009), Xiaosong, Zhen, Fangfang, y Shenqi (2008); y Boffoli, Bruno, Caivano, y Mastelloni (2008).

Para RQ2. ¿Cuáles son los beneficios y limitaciones identificados de SPG en el contexto de software, qué evidencias hay de los supuestos beneficios?

R6 responde con el $85 \%$ de los documentos a los beneficios y limitaciones de SPC, validaciones empíricas de SPC en software.

La mayor parte del conocimiento adquirido sobre SPC para procesos software se ha dado por analogía con otras disciplinas y por algunas experiencias de su aplicación en estos procesos, a pesar de las dificultades para su aplicación. Según 
Komuro (2006) existen evidencias de que el SPG tiene efectos positivos sobre la calidad de los productos, haciendo necesario centrarse más en los procesos que en el producto.

Para Manlove, et al., (2007) la implementación del SPC en los procesos software es lógicamente comentada, pero esto es problemático en la práctica por varias razones: el software es producido por personas, no por maquinas; hay significativas fuentes de variabilidad dentro del entorno de desarrollo del software que pueden ser difíciles de minimizar o controlar, es decir, existen múltiples causas comunes; los indicadores del comportamiento del proceso varían con el ciclo de desarrollo; y la mayoría de los datos de medición de software no se distribuye normalmente.

Los temas críticos para el éxito en la implementación de SPC son: la estabilidad del proceso, la capacidad de medición y la confiabilidad de los datos, en otras palabras, si se ha estandarizado el proceso, se han seleccionado las métricas correctas y se ha establecido un mecanismo confiable de recolección de datos, puede ser posible beneficiarse de la aplicación de las técnicas SPC.

Se ha detectado que existen cuatro problemas principales en el monitoreo del proceso de software con los gráficos de control: establecer líneas base; detectar anomalías; investigar las causas; y ajustar la sensibilidad. Para Baldassarre, Boffoli, Caivano, y Visaggio (2004), esto hace que las actividades de monitorear el proceso sean una tarea difícil; es así como, en un primer paso, se aclara la forma en que el SPG puede contribuir a resolver problemas del monitoreo y guiar a los profesionales hacia un uso más disciplinado de este enfoque, a partir de la experiencia recogida por los autores en investigaciones empíricas. No obstante para Boffoli, Bruno, Caivano, y Mastelloni (2008), la aplicación de SPC para el proceso de monitoreo todavía presenta limitaciones, por lo que hay aspectos relacionados con la medición de procesos de software, tales como la dificultad de recopilar métricas y su fiabilidad, y la selección de las características del proceso monitoreadas que deben ser considerados cuidadosamente. Los supuestos que rodean el SPG, como el predominio de los factores humanos en procesos de software, la teoría y la eficacia del monitoreo pueden repercutir en la implantación del SPC en contextos software

La correcta aplicación de un gráfico de control es fundamental ya que actúa como un auditor evaluando las no conformidades existentes acerca de un proceso/producto, siempre que las medidas preliminares necesarias se tomen. Por tanto, ofrece la oportunidad de detectar los problemas y mejorar los procesos de software, a través de una interfaz visual con una base científica.

En este orden de ideas, obtener los datos idóneos para la aplicación del SPG es indispensable para la fiabilidad de los límites de control, es decir los datos medidos deben ser los apropiados para aplicar las técnicas del SPC. En este sentido, el método de evaluación del repositorio de medición, como el expuesto por Perini, Rocha, y Falbo (2010), es una primera aproximación que permite evidenciar que el plan data collection mechanism has been established, it may be possible to benefit from the application of SPC techniques.

Four main problems in monitoring software process with control charts have been detected: establishing baselines, detecting anomalies, investigating the causes, and adjusting sensitivity. Baldassarre, Boffoli, Caivano, and Visaggio (2004) suggest that this makes the process of monitoring activities a difficult task; this is how, in a first step, SPC can contribute to solve problems of monitoring and guide professionals toward a more disciplined use of this approach, based on the experience gained by the authors in empirical researches. However, for Boffoli, Bruno, Caivano, and Massillon (2008), the application of SPC in monitoring processes still has limitations, so there are issues related to measuring software processes such as the difficulty of collecting metrics and its reliability, and the selection of monitored characteristics of the process that must be carefully considered. The assumptions surrounding the SPC, as the prevalence of human factors in software process, theory, and effectiveness of monitoring, may affect the implementation of SPG in software contexts.

The correct application of a control chart is essential because it acts as an auditor evaluating the existing non-conformities about a process/product, and ensuring that the necessary preliminary steps are always taken. Therefore, it provides an opportunity to identify problems and improve software processes through a visual interface with a scientific basis.

Obtaining the appropriate data for the application of SPC is therefore essential to the reliability of the control limits, i.e. the measured data should be appropriate to apply SPC techniques. In this sense, the evaluation method of measurement repository, as noted by Perini, Rocha, and Falbo (2010), is a first approach which makes evident that the measurement plan, the repository measurement structure, the defined measures, and data collection should be suitable for SPC, and provide useful information about the process behavior.

Finally, the cost of using SPC can be considered negligible after the initial effort. Indeed, the benefits are better process control, more effective detection of limit values, and monitoring the process of improvement actions. Hence, the profitability that can be achieved is high, especially in the medium and long term.

Twenty papers and empirical validation of SPC in software from the 25 primary sources are checked. The studies 
complementing solutions to limitations that demonstrate aspects and requirements considered important to the application of SPC techniques in the measurement of software processes, guiding the management of data and metrics to be considered valid to represent the aims and meet their objectives, include: Salin Monteiro and Marcal de Oliveira (2009), Paulk, Weber, Garcia, Chrissis, and Bush (1993), Batini and Sacannapieco (2006), Juran (1951), Kasunic, McCurley, Goldenson, and Zubrow (2011), Molina, Alzate, and Rincon (2009), Caballero (2008), Tarhan and Demirors (2006), Baldassarre, Caivano, and Visaggio (2006), Boffoli, Bruno, Caivano, and Mastelloni (2008), Montoni, Rocha, and Weber (2009), and Tarhan and Demirörs (2008).

For RQ3: Can SPG be applied to companies with minor maturity levels or emerging companies? And what would be the conditions, settings, characteristics, and environments to apply SPC in software processes?

R3 classifies 25\% of the documents that present study cases of SPC applied in measuring processes with CMMI $<4$ or emerging organizations.

From the experience of Weller (2000), control charts are typical in many high maturity organizations. However, with care, good evaluations of process stability can be obtained, indicating that SPC can be applied only when a subprocess has multiple executions. It is also stated that developers have successfully implemented SPC in many software projects.

In Wang et al. (2006) SPC is defined as a fundamental tool in measurement, analysis, and control. Many preliminary issues must be resolved before SPC can actually be effectively used in software organizations, thus needing enough observations to allow a proper definition of the process or project to identify and warn about anomalies and failures that a decision is based on, and adapting the necessary changes for a better performance.

The maturity level of the process is a factor that influences the amount of effort expended before using SPC. At this point the organizations with high maturity level have a stable and capable process that allows them to address this approach more effectively. On the other hand, it is not easy to implement SPC in an emerging software company; processes with relatively low maturity may require additional effort before the actual implementation of SPC but have the possibility of applying it (Sargut \& Deminörs, 2006).

Russ, Sperling, Rometsch, and Louis (2008), moreover, observe that CMMI practices have been implemented in de medición, la estructura del repositorio de medición, las medidas definidas y la colección de datos, deben ser idóneos para SPG, y proveer información útil del comportamiento del proceso.

Finalmente, el coste de usar SPC se puede considerar insignificante después del esfuerzo inicial. En efecto, los beneficios son un mejor control de proceso, una detección más eficaz de los valores extremos y un seguimiento del proceso de acciones de mejora. Por lo tanto, la rentabilidad que se puede conseguir es alta, especialmente a mediano y largo plazo.

Se comprueban veinte documentos como validaciones empíricas de SPC en software, de las 25 fuentes primarias. Los estudios que complementan soluciones a las limitaciones que evidencian aspectos y requisitos que son considerados de cuidado para la aplicación de las técnicas SPC en la medición de los procesos software, orientando el manejo de los datos y las métricas para que puedan considerarse válidos para representar lo que se pretende y cumplir sus objetivos se encuentran: Salin Monteiro y Marcal de Oliveira (2009); Paulk, Weber, Garcia, Chrissis, y Bush (1993); Batini y Sacannapieco (2006); Juran (1951); Kasunic, McCurley, Goldenson, y Zubrow (2011); Molina, Alzate, y Rincon (2009); Caballero (2008); Tarhan y Demirors (2006); Baldassarre, Caivano, y Visaggio (2006); Boffoli, Bruno, Caivano, y Mastelloni (2008); Montoni, Rocha, y Weber (2009); y Tarhan y Demirörs (2008).

Para RQ3. ¿Se puede aplicar SPG a empresas con niveles de madurez menor o empresas emergentes, cuáles serían las condiciones, los ajustes, las características y los ambientes para aplicar SPG en los procesos software?

R3 clasifica el 25\% de los documentos que presentan casos de estudio del SPC aplicado en la medición de proceso con CMMI $<4$ u organizaciones emergentes.

De la experiencia de Weller (2000), los gráficos de control son típicos en muchas organizaciones de alta de madurez. Sin embargo, si se tiene cuidado, se pueden obtener buenas evaluaciones de la estabilidad del proceso, indicando que se puede aplicar SPC sólo cuando un subproceso tiene múltiples ejecuciones. También afirma que los desarrolladores han aplicado con éxito SPC a muchos proyectos de software.

En Wang et al., (2006) se encuentra SPC inmerso como una herramienta fundamental en la medición, el análisis y el control, donde muchas cuestiones preliminares deben ser resueltas antes de que realmente SPC pueda ser utilizado de forma eficaz en las organizaciones de software, necesitando suficientes observaciones que permitan una adecuada definición del proceso o proyecto para identificar y alertar acerca de las anomalías y fallas en que se basa la toma de decisiones, adecuando los cambios necesarios para un mejor rendimiento.

El nivel de madurez del proceso es un factor que influye en la cantidad de esfuerzo gastado antes de usar SPG. En este punto las organizaciones con nivel de madurez alto tienen un proceso estable y capaz que les permite abordar de mejor manera este enfoque. Por otro lado, se encuentra que no es 
una tarea sencilla implementar el SPG en una empresa de software emergente, relativamente los procesos de baja madurez pueden requerir un esfuerzo adicional antes de la puesta en práctica real del SPC pero tienen la posibilidad de poderla aplicar (Sargut \& Deminörs, 2006).

Por su parte Russ, Sperling, Rometsch, y Louis (2008), han aplicado en la mayor parte de las unidades operativas las prácticas CMMI sobre madurez nivel 2 y 3, apoyando estas prácticas con herramientas integradas mediante el establecimiento de métodos y procesos de gestión cuantitativa con técnicas estadísticas para procesar problemas en el área de revisión por pares, inspección de código, requisitos, ingeniería, gestión de defectos latentes, ventas y gestión. La razón es que los altos niveles de madurez de CMMI® se implementan con una orientación a largo plazo, además de no proporcionar ninguna metódica o soporte de la herramienta. CMMI es un modelo de proceso y no una fuerza de reacción rápida.

Para RQ4. ¿Cuáles son las metodologías que apoyan una adecuada implantación de SPG en la gestión cuantitativa?

R4 clasifica al $84 \%$ de los documentos que guían la implementación del SPC a través de los procesos del ciclo de desarrollo, haciendo uso de una combinación de métodos, metodología de gestión Six Sigma, casos de estudio para software y otras herramientas estadísticas de calidad y transformación de datos, considerando el hecho de que la Ingeniería de Software requiere más indicadores, porque su diversidad de procesos es mayor.

Se debe comprender y tener claridad acerca de los factores que pueden influir en la selección de las métricas. Florac y Carleton (1999), y Piattini, García-Rubio, Garzás-Parra, y Genero-Bocco (2008) ofrecen procedimientos que pueden ayudar a desarrollar una comprensión de muchos de estos factores, de modo que se puedan elegir las medidas adecuadas. Es importante tener en cuenta que el objetivo es encontrar medidas que proporcionen información pertinente.

Manlove y Kan (2007) proponen el Método IESMR, Instrumento para la Evaluación de la Idoneidad del Repositorio de Medición para SPC, en el cual las medidas y los datos son evaluados a través del método; si la colección de datos puede ser trazada correctamente en un gráfico de control, entonces las medidas se consideran apropiadas para SPC y proveen información útil acerca del comportamiento del proceso e información relacionada con los objetivos de la organización. De lo contrario el repositorio de medición tendría que ser reestructurado.

El punto de partida para comprender si SPC se puede utilizar en el software y cómo, es su contribución en la solución de los problemas existentes en el monitoreo de procesos software, a partir de cuatro patrones generales propuestos por Baldassarre, Boffoli, Caivano, y Visaggio (2008) y por Caivano (2000) quienes determinan una directriz en el uso de los gráficos de control en software, métodos de monitoreo para la detección de anomalías, test de estabilidad y ajustes a realizar. SPC se convierte en un requerimiento para la mejora de most of the operative units on maturity level 2 and 3 supporting these practices with integrated tools by establishing methods and quantitative management processes with statistical techniques to process problems in the area of peer review, code inspection, requirements, engineering, management of latent defects, sales, and management. The reason is that high levels of maturity of $\mathrm{CMMI} \AA$ are implemented with long-term guidance, besides providing no methodical or tool support. CMMI is a process model and not a rapid reaction force.

For RQ4: What are the methodologies that support an adequate SPC implementation in quantitative management?

R4 classifies $84 \%$ of the documents that guide the implementation of SPC through the development cycle processes, using a combination of methods, Six Sigma management methodology, study cases for software, and other quality statistical tools and data processing, considering the fact that software engineering requires more indicators because its diversity of processes is greater.

It must be understood the factors that may influence the selection of metrics. Florac and Carleton (1999), and Piattini, Garcia-Rubio, Garzas-Parra, and Gender-Bocco (2008) offer procedures that can help to develop an understanding of many of these factors, so that they can choose the appropriate measures. It is important to note that the objective is to find measures that provide relevant information.

Manlove and Kan (2007) propose the IASMR method, Instrument for Assessing Suitability of the Measurement Repository to SPC, in which measures and data are evaluated. If the collection of data can be plotted correctly on a control chart, then the action is considered appropriate for SPC and provides useful information about the behavior of the process and information related to the objectives of the organization. Otherwise, the measurement repository would have to be restructured.

The starting point is to understand whether SPC can be used in software and its contribution to the solution of the existing problems in software process monitoring, from four general patterns proposed by Baldassarre, Boffoli, Caivano, and Visaggio (2008) and Caivano (2000), who determined a guideline for the use of control charts in software, monitoring methods for the detection of anomalies, stability tests, and adjustments to make.

SPC becomes a requirement for improving the quality of the processes. A suitable method for the implementation of 
SPC in quantitative management in software process improvement is Six Sigma. Although in its most fundamental form Six Sigma is a quality measure, the term is now used to encompass concepts and tools designed to help to achieve almost perfect processes (Tayntor, 2007). The statistical tools used to solve different problems are similar to those used in other strategies to improve modern quality. However, Six Sigma emphasizes the application of these tools in a methodical and systematic way to achieve improvements with economically measurable results (Barbiero, et al., 2005), so its high standards of achievement make necessary the knowledge and use of various statistical tools for the articulation of SPC at corresponding stages DMAIC: Define-Measure-Analyze-Improve-Control.

For Barbiero, Flury, Pagura, Quaglino, and Ruggieri (2005) the Six Sigma methodology is a strong strategy to achieve important improvements; they conclude that some big companies are beginning to adopt it, and also that the interest of some PYMES is evident.

The studies of Russ, Sperling, Rometsch, and Louis (2008), Xiaosong, Zhen, Fangfang, and Shenqi (2008), and Park, Choi, and Baik (2007) demonstrate results using the Six Sigma methodology for software quality, showing that this method is feasible in processes improvement and, undoubtedly, applicable in Software Engineering. Other studies that complement the experience with Six Sigma in Project management are those of Lefcovich (2004), Tayntor (2007), Xiaosong, Zhen, Fangfang, and Shenqi (2008), Muro (2007), and López (2007).

For RQ5. What activities and control methods are being raised for monitoring software distributed processes in companies with minor maturity level or emerging companies?

R 5 classifies the $4 \%$ of the documents that favor the starting point. Caivano (2011) shows how to measure and, consequently, to manage companies in business and industries with Six Sigma, and provides principles and tools that can be applied to any process as a means used to measure defects or error rates.

\section{Conclusions and Future Work}

The systematic review has demonstrated the primary studies that show a current state of SPC and its application to advanced quantitative management in software processes. It allows to answer the questions concerning the aspects of the software process to consider to implement SPC, the criteria for selecting control charts, metrics, monitoring, and imple- la calidad de los procesos. Un método apropiado para la implantación de SPG en la gestión cuantitativa en el mejoramiento de procesos software es Six Sigma. Aunque en su forma más fundamental Six Sigma es una medida de la calidad, el término se utiliza ahora para abarcar conceptos y herramientas diseñados para ayudar a lograr procesos casi perfectos (Tayntor, 2007). Las herramientas estadísticas que se utilizan para dar solución a los distintos problemas son similares a las empleadas en otras estrategias de mejora de la calidad modernas, sin embargo, Six-Sigma hace énfasis en la aplicación de estas herramientas en forma metódica y sistemática para lograr mejoras con resultados medibles económicamente (Barbiero, et al., 2005), por lo que su alto nivel de exigencia de logros en calidad hace necesario el conocimiento y la utilización de variadas herramientas estadísticas, para la articulación de SPC en las correspondientes etapas DMAIC: Definir-Medir-Analizar-Mejorar-Controlar.

Para Barbiero, Flury, Pagura, Quaglino, y Ruggieri (2005) la metodología Six Sigma es una fuerte estrategia para lograr importantes mejoras; concluyen que algunas empresas grandes están comenzando a adoptarla y que además, se empieza a evidenciar el interés de algunas PYMES.

Los estudios de Russ, Sperling, Rometsch, y Louis (2008), Xiaosong, Zhen, Fangfang, y Shenqi (2008), y Park, Choi, y Baik (2007) evidencian resultados usando la metodología Six Sigma sobre la calidad del software indicando que este método es factible en la mejora de los procesos y, sin duda, aplicable en el campo de la Ingeniería del Software. Otros estudios que complementan la experiencia con Six Sigma en la gestión de proyectos son los de Lefcovich (2004), Tayntor (2007), Xiaosong, Zhen, Fangfang, y Shenqi (2008), Muro (2007) y López (2007).

Para RQ5. ¿Qué actividades y métodos de control están siendo propuestas para el monitoreo de procesos software distribuidos en empresas con niveles de madurez menor o empresas emergentes?

R5 clasifica el $4 \%$ de los documentos que propician el punto de partida. Caivano (2011) muestra la manera de medir y, en consecuencia, la forma de gestionar las empresas en los negocios y las industrias con Six Sigma, y ofrece principios y herramientas que se pueden aplicar a cualquier proceso, como un medio utilizado para medir los defectos o las tasas de error.

\section{Conclusiones y trabajo futuro}

La revisión sistemática ha permitido obtener los estudios primarios que exhiben un estado actual del SPC y de su aplicación a la gestión cuantitativa avanzada de procesos software, y permite responder a las preguntas sobre los aspectos a considerar del proceso software para la aplicación del SPC, los criterios de elección de los gráficos de control, las métricas, el monitoreo y los métodos de implementación para la gestión del proceso software con SPC y la mejora de la calidad.

El coste de usar SPC puede considerarse insignificante después del esfuerzo inicial. En efecto, los beneficios son un me- 
jor control de proceso, una detección más eficaz de los valores extremos y la posibilidad de realizar un seguimiento del proceso de las acciones de mejora. Por lo tanto, la rentabilidad que se puede conseguir es alta, especialmente a mediano y largo plazo.

Los resultados obtenidos del análisis de la literatura han permitido establecer el punto de partida para definir una metodología de implantación del SPC, donde se identifiquen los métodos más adecuados para aplicar SPG como una estrategia efectiva para la mejora de la gestión cuantitativa de los procesos software junto a Six Sigma, un programa mayor de gestión, enfocado a la mejora continua, como una primera etapa que debe establecerse para articularse con otras responsabilidades dentro de un modelo de gestión para el DGS.

\section{Agradecimientos}

Este trabajo ha sido financiado por los siguientes proyectos: ORIGIN (CDTI-MICINN and FEDER IDI2010043(1-5); PEGASO/MAGO (MICINN and FEDER, TIN2009-13718-C02-01), y ALTAMIRA (Junta de Comunidades de Castilla-La Mancha, Fondo Social Europeo, PII2I09-0106-2463). SR mentation methods for software process management with SPG and quality improvement.

The cost of using SPC can be considered negligible after initial effort. Indeed, the benefits are better process control, more effective detection of limit values, and the ability to track the process of improvement actions. Therefore, the profitability that can be achieved is high, especially in the medium and long term.

The results of the analysis of literature have established the starting point for defining a methodology of implementation of SPC, where the most appropriate methods for its application are identified as effective strategy for improving the quantitative management of software processes with Six Sigma. This is a greater management program focused on continuous improvement, as a first step that must be established to coordinate with other responsibilities within a management model for the DGS.

\section{Acknowledgments}

This work was funded by ORIGIN (CDTI-MICINN and FEDER IDI-2010043(1-5), PEGASO/MAGO (MICINN and FEDER, TIN2009-13718-C02-01), and ALTAMIRA (Castilla-La Mancha Regional Communities Board, European Social Fund, PII2I09-0106-2463). ST

\section{References / Referencias}

Alzate Naranjo, J., \& Molina Correa, A. (2009). Gestión cuantitativa del proceso de desarrollo de software. Medellín, Colombia: Universidad EAFIT.

Barbiero, C., Flury, M., Pagura, J., Quaglino, M., \& Ruggieri , M. (2005). La importancia de la estadística en estrategias de mejora continua de la calidad. La metodología Seis Sigma. (Vol. Décimas Jornadas "Investigaciones en la Facultad"). Rosario, Argentina: Universidad Nacional de Rosario.

Baldasarre, M. T., Caivano, D., Kitchenham, B., \& Visaggio, G. (2007). Systematic Review of Statical Process Control: An Experience Report. 11th International Conference on Evaluation and Assessment in Software Engineering (EASE). Keele, UK: Keele University.

Baldassarre, M. T., Boffoli, N., Caivano, D., \& Visaggio, G. (2008). A hands on approach for Teaching Systematic Review. In Product-focused software process improvement (pp. 415-426). Berlin Heidelberg, Germany: Springer.

Baldassarre, M., Caivano, D., \& Visaggio, G. (2006). Non Invasive Monitoring of a Distributed Maintenance Process. Instrumentation and Measurement Technology Conference, 2006. IMTC 2006. Proceedings of the IEEE (pp. 1098-1103). Piscataway, NJ: IEEE.

Baldassarre, T., Boffoli, N., Caivano, D., \& Visaggio, G. (2004). Manging software process improvement (SPI) through statical rocess control (SPC). In Product Focused Software Process Improvement (pp. 30-46). Berlin Heidelberg, Germany: Springer.

Batini, C., \& Sacannapieco, M. (2006). Data quality: concepts, methodologies and techniques. Berlin, Germany: Springer Verlag.

Boffoli, N., Bruno, G., Caivano, D., \& Mastelloni, G. (2008). Statistical process control for software: a systematic approach. Proceedings of the Second ACM-IEEE international symposium on Empirical software engineering and measurement (pp. 327-329). New York, NY: ACM.

Brereton, P., Kitchenham, B., Budgen, D., Turner, M., \& Khalil, M. (2005). Employing sistematic literature review: An experience report [unpublished draft]. Keele, UK: School of Computing \& Mathematics, Keele University.

Burr, A. \& Owen, M. (1996). Statical methods for software quality. Scottsdale, AZ: Coriolis

Caballero , I. (2008). Introducción a la calidad de los datos y de la información. Escuela Superior de Informatica. Ciudad Real, Spain: Universidad Castilla la Mancha.

Caivano, D. (2000). Statical process control. (SERLAB, Ed.) Bari, Italy: Università degli Studi di Bari.

Caivano, D. (2011). Six Sigma for Software [Case Study]. // seminario si incentrerà in maniera pratica. Italy. 
Card, D., Domzalski, K., \& Davies, G. (2008). Making statistics part of decision making in an engineering organization. IEEE Software, 25(3), 37-47.

Card, D. (1994). Statical process control for software. IEEE SOftware, 11(3), 95-97.

Carleton, A., \& Florac, A. (1999). Statically Controlling the Software Process. The 99 SEI Software Engineering Symposium. Pittsburgh, PA: Software Engineering Institute, Carnegie Mellon University.

Ferreiro, O. P. (2010). Control estadístico de procesos y estrategias Seis Sigma. Fonte: http://www.oocities.org/es/foro2 control_de_procesos/genlace1.pdf

Florac, W. A., \& Carleton, A. D. (1999). Measuring the software process: statical process control for software process improvement. Indianapolis, IN: Pearson.

Gardiner, J., \& Montgomery, D. (1987). Using statistical control of charts for software quality control. Quality and Reliability Engineering International, 3, 15-20.

Genero, M., Fernández, A. M., Nelson, H. J., \& Piattini, M. (2011). How to perform systematic reviews: Theory and examples. In A. R. group (Ed.), Metodologías y Técnicas de Investigación en Informática. Universidad Castilla - La Mancha: Ciudad Real, Spain.

Hale, C., \& Row, M. (2012). Do Not Get Out of Control: Achieving Real-time Quality and Performance. Retrieved from Crosstlak on line, http://www.crosstalkonline.org/storage/issue-archives/2012/201201/201201-Hale.pdf.

ISO. (2003). Guidance on statistical techniques for ISO 9001:2000. Geneva, Switzerland: ISO.

Juran, J. M. (1951). Juran's quality control handbook. New York, NY: McGraw Hill.

Kasunic, M., McCurley, J., Goldenson, D., \& Zubrow, D. (2011). An investigation of techniques for detecting data anomalies in earned value management data [tech. Rep-]. Pittsburgh, PA: Carnegie Mellon University.

Kitchenham, B. (2004). Procedures for performing systematic reviews [technical report TR/SE0401]. Keele, UK: Keele University.

Kitchenham, B. (2007). Guidelines for performing systematic literature reviews in softwrare engineering [EBSE technical report]. (D. o.-U. Sotfware Engineering Group - Keele University) Keele, UK: Keele University.

Komuro, M. (2006). Experiences of Applying SPC Techniques to software Development Processes. Proceedings of the 28th international conference on Software engineering (pp. 577-584). New York, NY: ACM.

Lantzy, M. (1992). Application of Statical Process Control to the Software Process. Proceeding WADAS '92 Proceedings of the ninth Washington Ada symposium on Ada: Empowering software users and developers (pp. 113-119). New York, NY: ACM.

Lefcovich, M. L. (2004). Six Sigma, un nuevo paradigma en gestión. Buenos Aires, Argentina: El Cid.

López. (2007). Six Sigma aplicado a la gestión de Mantenimiento en la empresa Drummond Ltd [monografía]. Universidad Industrial de Santander: Bucaramanga, Colombia.

Manlove, D., \& Kan, S. (2007). Practical statistical process control for software metrics. Software Quality Professional Magazine, 9(4), 15-26.

Molina C., A. M., Alzate N., J. A., \& Rincon B., R. D. (2009). Gestión Cuantitativa del proceso de desarrollo de software [thesis]. Escuela de Ingeniería de Sistemas. Medellin, Colombia: Universidad EAFITs.

Montoni, M., Rocha, A., \& Weber, K. C. (2009). MPS. BR: A succesful program for softwrae process improvement in Brazil. Journal of Software Maintenance and Evolution. Research and Practice , 14(5), 289-300.

Muro, G. (2007). Aplicación de la metodología "Six Sigma” (6 o) a un mantenimiento preventivo de una turbina eólica [degree paper]. Universidad Pública de Navarra: Pamplona, Spain.

Park, Y., Choi, H., \& Baik, J. (2007). A Framework for the Use of Six Sigma Tools in PSP/TSP. In Software Engineering Research, Management \& Applications, 2007. SERA 2007. 5th ACIS International Conference on (pp. 807-814). Los Alamitos, CA: IEEE Computer Society.

Paulk, M. C., Weber, C. V., Garcia, S. M., Chrissis, M., \& Bush, M. (1993). Key practices of capability maturity model [Tech. Rep.] (Vol. Version 1.1). (S. E. Institute, Ed.) Pittsburgh, PA: Carnegie Mellon University.

Perini, M. B., Rocha, A. R., \& Falbo, R. D. (2010). Evaluating the Suitability of a Measurement Repository for Statical Process Control. In ESEM'10 (Ed.), Proceedings of the 2010 ACM-IEEE International Symposium on Empirical Software Engineering and Measurement (p. 27). New York, NY: IEEE.

Piattini V., M. G., García Rubio, F. Ó., Garzás Parra, J., \& Genero Bocco, M. F. (2008). Medición y estimación del software. Madrid, Spain: Ra-Ma.

Pino, F. J., García, F., \& Piattini, M. (2007). Software process improvement in small and medium software enterprises: a systematic review. Software Quality Journal, 16(2), 237-261.

Ruiz-Falcó, A. (2006). Control estadístico de procesos [class notes]. Madrid, Spain: Universidad Pontificia Comillas.

Russ, R., Sperling , D., Rometsch, F., \& Louis, P. (2008). Applying Six Sigma in the field of software engineering. In Software process and product measurement (pp. 36-47). Berlin Heidelberg, Germany: Spinger.

Salin Monteiro, L. F., \& Marcal de Oliveira, K. (2009). Defining a catalog of indicators to support process. Journal of Software Maintenance and Evolution: Research and Practice, 23(6), 395-422.

Sargut, K., \& Deminörs, O. (2006). Utilization of statical process control (SPC) in emergent software organizations: pitfalls and suggestions. Software Quality Journal, 14(2), 135-157.

Tarhan , A., \& Demirörs, O. (2008). Assessment of software process and metrics. Lecture Notes in Computer Science, 4895 , 102-113. 
Tarhan, A., \& Demirors, O. (2006). Investigating suitability of software process and metric for statical process control. In Software Process Improvement (pp. 88-99). Berlin Heidelberg, Germany: Springer.

Tayntor, C. (2007). Six Sigma software development (Vol. 2). Boca Raton, FL: Auerbach.

Wang , Q., Gou, L., Jiang, N., \& Che, M. (2007). An empirical study on establishing quantitative. Lecture Notes in Computer Science, 4470, 233-245.

Wang, Q., Jiang, N., Gou, L., Liu, X., Li, M., \& W, Y. (2006). BSR: A Statistic-Based Approach for Establishing. Proceedings of the 28th international conference on Software engineering (pp. 585-594). New York, NY: ACM.

Wang, Q., Jiang, N., Gou, L., Liu, X., Li, M., \& Wang, Y. (2006). BSR: A Statistic-based Approach for Establishing and Refining Software Process Performance Baseline. ICSE '06 Proceedings of the 28th international conference on Software engineering (pp. 585-594). New York, NY: ACM.

Weller, E. (2000). Practical applications of statistical process control. IEEE Software, 17(3), 48-55.

Xiaosong, Z., Zhen, H., Fangfang , G., \& Shenqi, Z. (2008). Research on the Application of Six Sigma in Software Process Improvement. Intelligent Information Hiding and Multimedia Signal Processing, 2008. IIHMSP'08 International Conference (pp. 937-940). Piscataway, NJ: IEEE. 


\section{CURRICULUM VITAE}

Bibiana Yeaneth Garcés Constain Master in Informatics Engineering, Master in Advanced Computer Technologies from Universidad de Castilla La Mancha (Spain), and Engineering in Industrial Automation from the Universidad del Cauca (Colombia). She is currently Professor and Coordinator of Social Projection at the Corporación Universitaria de Comfacauca's Engineering Program. She also serves as a consultant on implementation and improvement of software factories in Kybele Consulting Colombia SAS. His areas of research and professional interest are quality and statistical process control software for advanced global software process improvement.

Francisco José Pino Correa Doctor in Informatics Engineering from Universidad de Castilla-La Mancha (Spain), Electronics and Telecommunications Engineer, and Specialist in Networks and Telematics Services from Universidad del Cauca (Colombia). He is a professor attached to the Faculty of Electrical Engineering and Telecommunications, member of IDIS Research Group (Research and Development in Software Engineering) at the Universidad del Cauca, and founder of Kybele Consulting Colombia SAS, an advisory company in quality and process, products, and services software improvement. Chief Auditor AENOR ISO 15504-SPICE. His research and professional interests are quality and process improvement of software development in small enterprises and multi-model environments. 